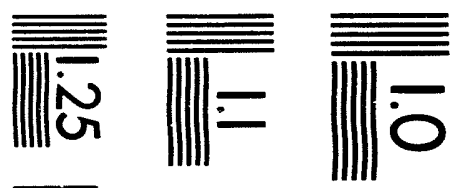

$$
\begin{aligned}
& \text { 霞 }
\end{aligned}
$$

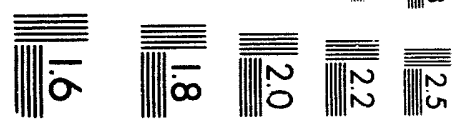



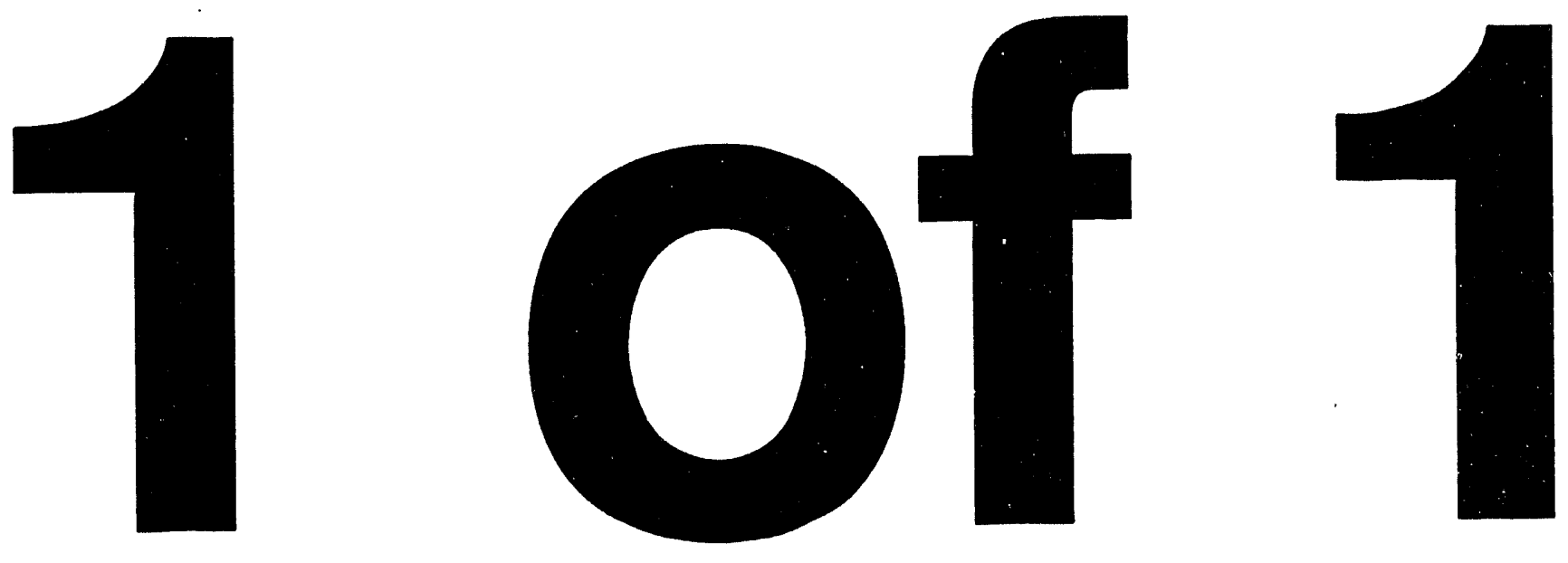


\title{
Remote Excavation System Test Plan
}

\author{
TTP Numbers: \\ ID-3320-04, \\ OR-1320-14, \\ RL-3320-17, \\ SF-2320-02, \\ AL-2320-07
}

S. Walker

R. A. Hyde

Published May 1993

Idaho National Engineering Laboratory

EG\&G Idaho, Inc.

Idaho Falls, Idaho 83415

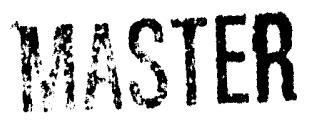

DISTRIBUTION OF THIS DOCUMENT IS UNLIMITED

Prepared for the

U.S. Department of Energy

Office of Technology Development

Under DOE Idaho Operations Office

Contract DE-AC07-76ID01570 


\title{
Remote Excavation System Test Plan
}

\author{
EGG-WTD-10703
}

Prepared by

Stepleme

S. Walker, Principal Investigator

$\frac{1 / / / / L /}{\text { R. A. Hyde, Pogram Manager. BWRP }}$

Reviewed by

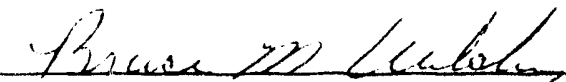

B. M. Wilding, Program Manager, RTDP

Westinghouse Idaho Nuclear Co.

Approved by

K.M. Kostdlnik, BWID Coordinator
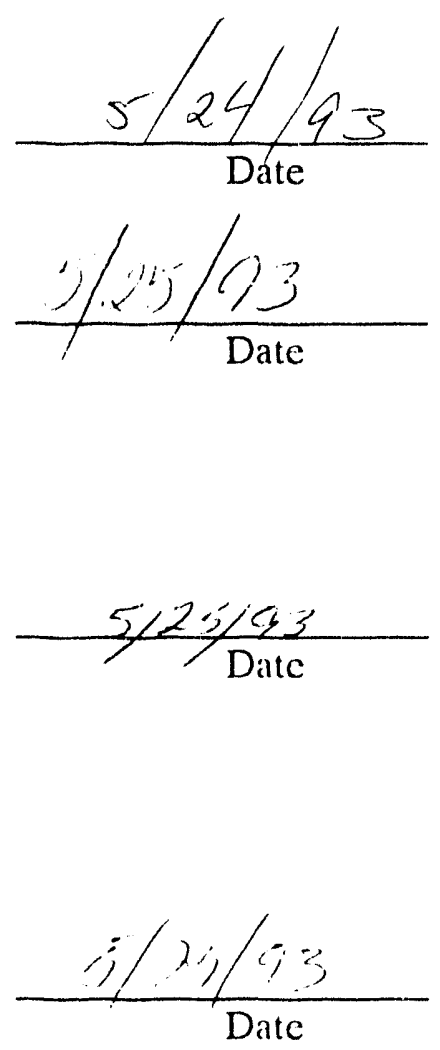


\section{ABSTRACT}

The Office of Technology Development (OTD) established the Robotics Technology Development Program (RTDP) to integrate robotic development activities on a national basis; provide needs-oriented, timely, and economical robotics technology to support environmental and waste operations activities at Department of Energy (DOE) sites; and provide the focus and direction for the near term (kess than five years) and guidance for the long-term (five to twenty years) rescarch and development eflorts for site-specific problems. The RTDP consists of several programs including the Buried Waste Robotics Program (BWRP), which addresses remote buried waste applications.

The Remote Excavation System (RES) was developed under the RTDP to provide a safer method of excavating hazardous materials for both the DOE and the Department of Defense (DOD). The excavator, initially developed by the DOD as a manually-operated small excavator, has been modified for teleoperation with joint funding from the BWRP and the DOD. The Buried Waste Integrated Demonstration (BWID) and the Uranium Soils Integrated Demonstration (USID) are funding the demonstration, testing, and evaluation of the RES covered in this test plan. This document covers testing both at Oak Ridge National Laboratory (ORNL) and the Idaho National Enginecring Laboratory (INEI), as funded by BWID and USID.

This document describes the tests planned for the RES demonstration for the BWRP. The purposes of the lest plan are 1) to establish test parameters to ensure that the demonstration results are deemed useful and usable and 2) to demonstrate performance in a safe manner within all regulatory requirements. 


\section{SUMMARY}

The purpose of the RES project is to test and demonstrate the capabilities of the excavation system and of the remotely-operated controls. The tests will be divided into two catcgories: (1) system performance test objectives and (2) component performance test objectives. The overall product will include test data on a mechanism to retrieve buried waste and an advanced control system that is applicable to various types of remote excavation. Demonstration of soil skimming capabilitics of the RES for the Uranium Soils Integrated Demonstration (USID) at the INEL are included in this document. These tests include (1) preliminary equipment tests at ORNL, (2) open-air removal of overburden in layers from the retrieval cells of the INEL cold test pit, and (3) waste retrieval from the cold test pit retrieval cells in a temporary enclosure with contamination control methods.

The report details the analytical methods to be performed and how the RES test data will be validated, verified, and recorded through measurement to determine precision and accuracy in accordance with established procedures.

The report outlines Data Quality Objectives lor the RES demonstration testing, equipment and instrument procedures used, health and safety issues related to the demonstration, residuals management, how the project will be managed in accordance with the regulations of the facility at which it is performed, and regulatory requirements for the demonstrations at the INEL, including NEPA and OSHA issues (if applicable).

Information on how the project will he documented, in compliance with the BWID PMP, through management of electronic data, management of reports, and management of logbooks is also given. 


\section{CONTENTS}

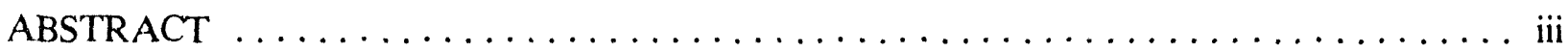

SUMMARY $\ldots \ldots \ldots \ldots \ldots \ldots \ldots \ldots \ldots \ldots \ldots \ldots \ldots \ldots \ldots \ldots \ldots$

ACKNOWLEDGMENTS $\ldots \ldots \ldots \ldots \ldots \ldots \ldots \ldots \ldots \ldots \ldots \ldots \ldots \ldots \ldots$

ACRONYMS $\ldots \ldots \ldots \ldots \ldots \ldots \ldots \ldots \ldots \ldots \ldots \ldots \ldots \ldots \ldots \ldots \ldots \ldots \ldots \ldots \ldots i i$

1. INTRODUCTION $\ldots \ldots \ldots \ldots \ldots \ldots \ldots \ldots \ldots \ldots \ldots \ldots \ldots \ldots \ldots \ldots$

1.1 The RES Technology Description and Background $\ldots \ldots \ldots \ldots \ldots \ldots \ldots \ldots$

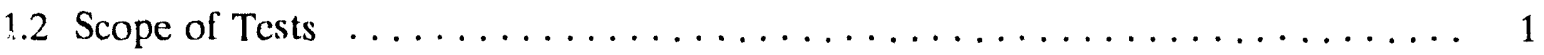

1.3 Purpose and Objectives of Test $\ldots \ldots \ldots \ldots \ldots \ldots \ldots \ldots \ldots \ldots \ldots \ldots$

1.3.1 System Performance Test Objectives $\ldots \ldots \ldots \ldots \ldots \ldots \ldots \ldots$

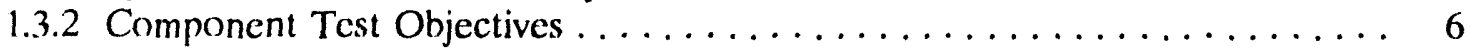

1.4 Technology Agreement $\ldots \ldots \ldots \ldots \ldots \ldots \ldots \ldots \ldots \ldots \ldots \ldots \ldots \ldots$

2. ORGANIZATION AND RESPONSIBILITIES $\ldots \ldots \ldots \ldots \ldots \ldots \ldots \ldots \ldots$

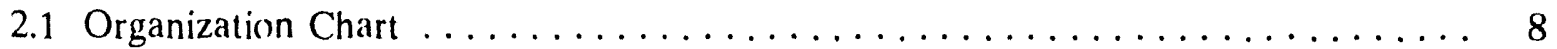

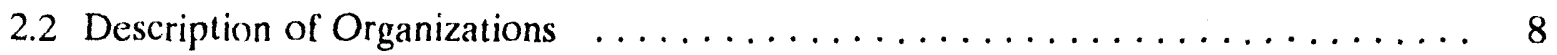

2.2.1 Buried Waste Robotics Program (BWRP) $\ldots \ldots \ldots \ldots \ldots \ldots \ldots \ldots$

2.2.2 Buried Waste Integrated Demonstration (BWID) Program ......... 8

2.2.3 Uranium Soils Integrated Demonstration (USID) Program $\ldots \ldots \ldots \ldots \ldots$

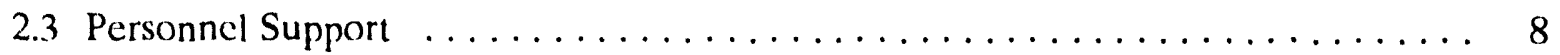

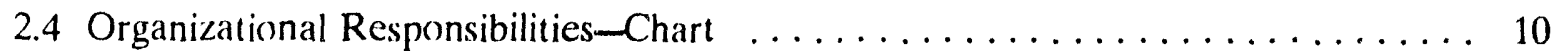

2.5 Responsibilitics of each National Laboratory $\ldots \ldots \ldots \ldots \ldots \ldots \ldots \ldots \ldots$

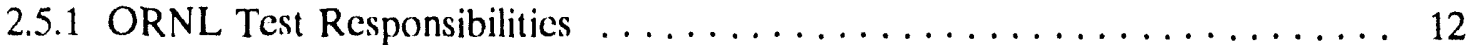

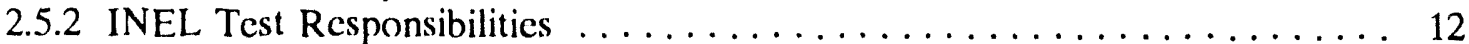

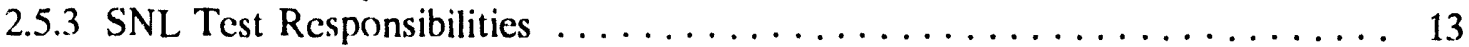

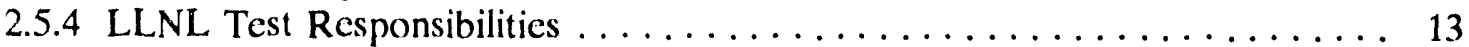

2.6 Qualifications and Training Required $\ldots \ldots \ldots \ldots \ldots \ldots \ldots \ldots \ldots$

3. DESCRIPTION OF TESTS $\ldots \ldots \ldots \ldots \ldots \ldots \ldots \ldots \ldots \ldots \ldots \ldots \ldots \ldots$

3.1 System Performance Tests $\ldots \ldots \ldots \ldots \ldots \ldots \ldots \ldots \ldots \ldots \ldots \ldots$ 
3.1 .1 BWID Test Requirements $\ldots \ldots \ldots \ldots \ldots \ldots \ldots \ldots \ldots \ldots \ldots \ldots \ldots$

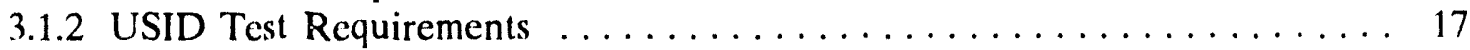

3.2 Component Tests $\ldots \ldots \ldots \ldots \ldots \ldots \ldots \ldots \ldots \ldots \ldots \ldots \ldots \ldots$

3.2.1 Evaluate The Control System $\ldots \ldots \ldots \ldots \ldots \ldots \ldots \ldots \ldots \ldots \ldots$

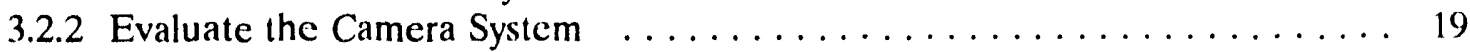

3.2.3 Evaluate the Data Communications System . . . . . . . . . . . . 19

3.2 .4 Evaluate the RES Vehicle. . . . . . . . . . . . . . . . . . . . . . 20

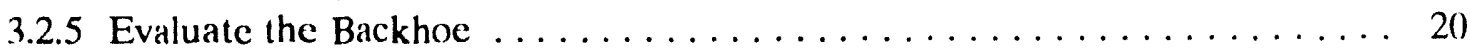

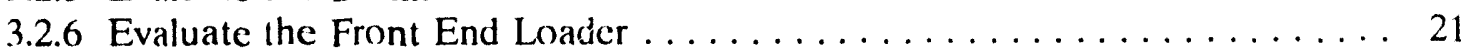

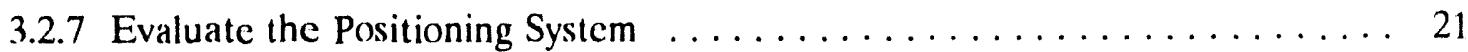

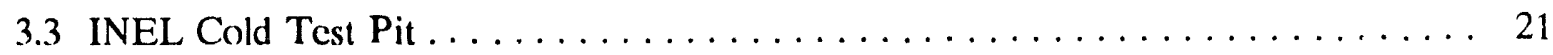

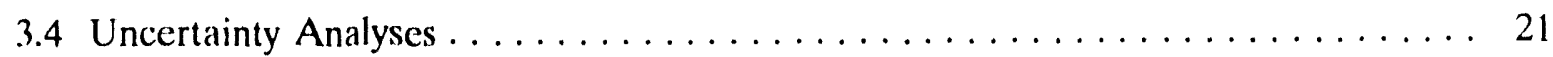

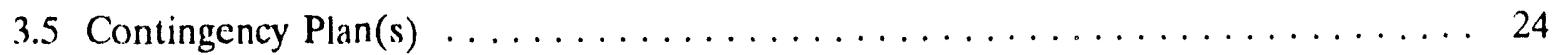

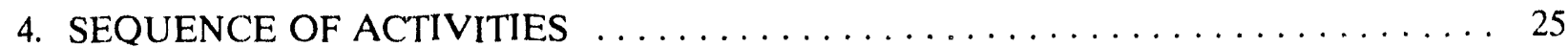

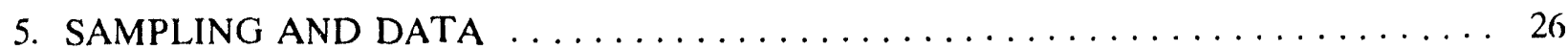

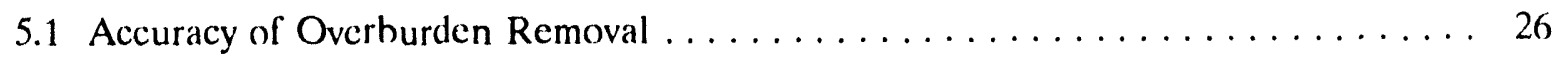

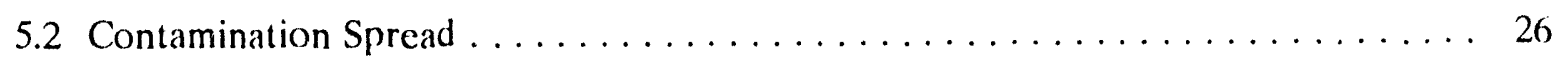

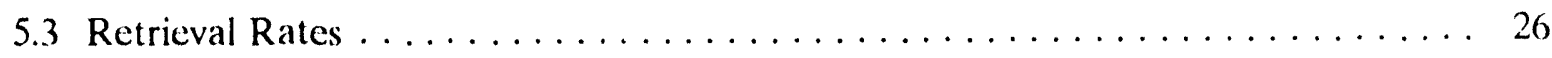

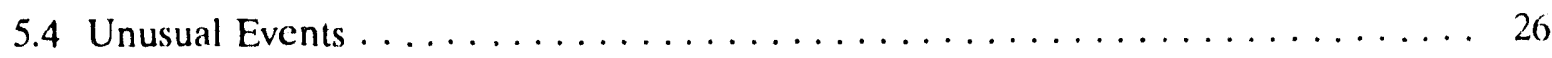

6. DOCUMENT CONTROL $\ldots \ldots \ldots \ldots \ldots \ldots \ldots \ldots \ldots \ldots \ldots \ldots \ldots \ldots$

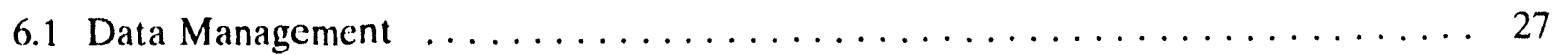

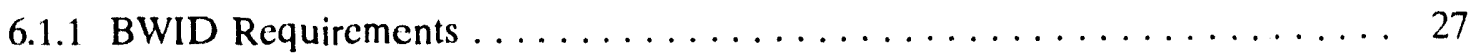

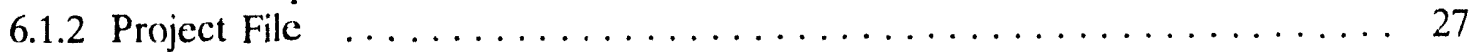

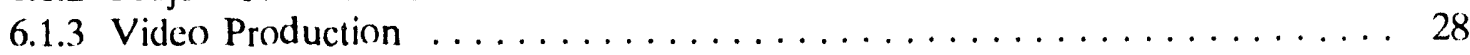

6.1 .4 Data Reporting $\ldots \ldots \ldots \ldots \ldots \ldots \ldots \ldots \ldots \ldots \ldots \ldots \ldots$

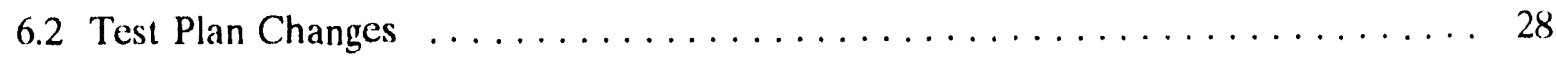

6.3 Other Documents ............................... 29

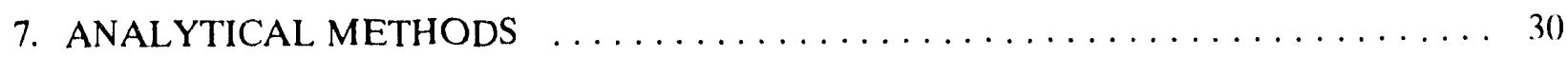

7.1 Gravimetric Analysis of Filters $\ldots \ldots \ldots \ldots \ldots \ldots \ldots \ldots \ldots \ldots \ldots \ldots \ldots \ldots \ldots \ldots$ 
8. DATA REDUCTION, VALIDATION, AND VERIFICATION $\ldots \ldots \ldots \ldots \ldots \ldots$

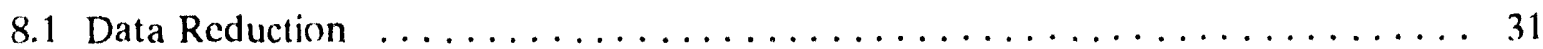

8.2 Data Validation/Verification/Recording $\ldots \ldots \ldots \ldots \ldots \ldots \ldots \ldots \ldots \ldots \ldots$

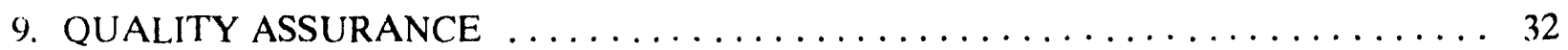

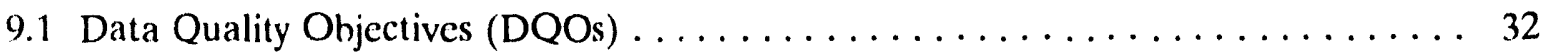

9.2 Internal Quality Control Checks $\ldots \ldots \ldots \ldots \ldots \ldots \ldots \ldots \ldots \ldots \ldots \ldots \ldots \ldots$

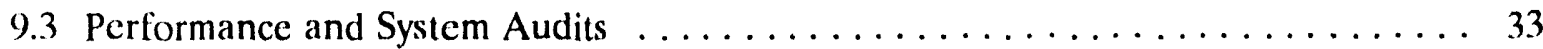

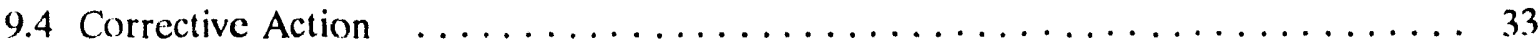

10. EQUIPMENT AND INSTRUMENTS $\ldots \ldots \ldots \ldots \ldots \ldots \ldots \ldots \ldots \ldots \ldots$

11. SUPPLIES, UTILITIES, AND FACILITIES $\ldots \ldots \ldots \ldots \ldots \ldots \ldots \ldots \ldots$

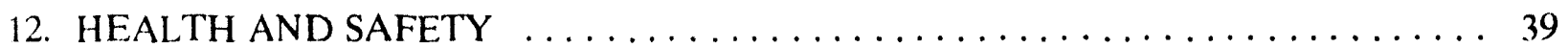

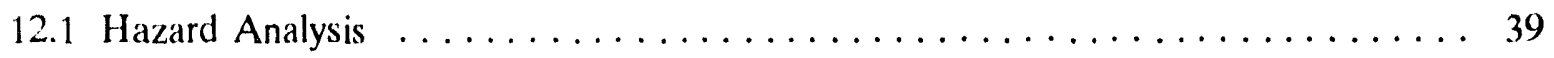

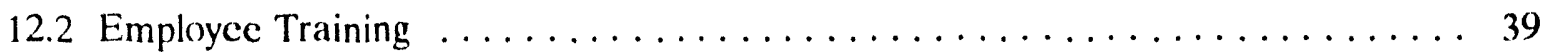

12.3 Protective Equipment $\ldots \ldots \ldots \ldots \ldots \ldots \ldots \ldots \ldots \ldots \ldots \ldots \ldots \ldots \ldots$

12.4 Emergency Response Plan $\ldots \ldots \ldots \ldots \ldots \ldots \ldots \ldots \ldots \ldots \ldots \ldots \ldots \ldots$

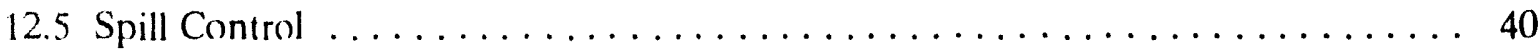

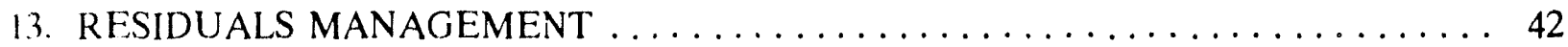

14. REGULATORY REQUIREMENTS $\ldots \ldots \ldots \ldots \ldots \ldots \ldots \ldots \ldots \ldots \ldots$

14.1 National Environmental Policy Act $\ldots \ldots \ldots \ldots \ldots \ldots \ldots \ldots \ldots \ldots \ldots$

14.2 Occupational Safety and Health Administration (OSHA) $\ldots \ldots \ldots \ldots \ldots$

15. REFERENCES $\ldots \ldots \ldots \ldots \ldots \ldots \ldots \ldots \ldots \ldots \ldots \ldots \ldots \ldots \ldots$

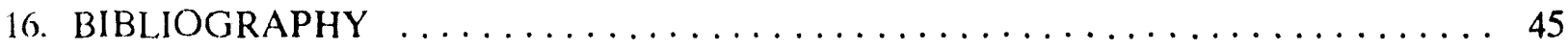

Appendix A-Enginecring Test Sequences $\ldots \ldots \ldots \ldots \ldots \ldots \ldots \ldots \ldots \ldots \ldots \ldots \ldots$

Appendix B-Formulas for DQO Calculations $\ldots \ldots \ldots \ldots \ldots \ldots \ldots \ldots \ldots \ldots \ldots$ 


\section{FIGURES}

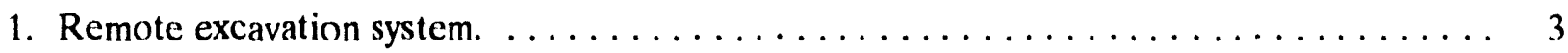

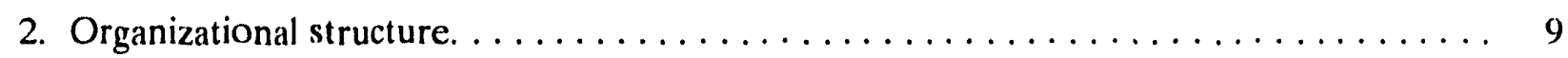

3. RES test matrix responsibilities $\ldots \ldots \ldots \ldots \ldots \ldots \ldots \ldots \ldots \ldots \ldots \ldots \ldots \ldots \ldots \ldots$

4. Sequence of activities during soil skimming tests $\ldots \ldots \ldots \ldots \ldots \ldots \ldots$

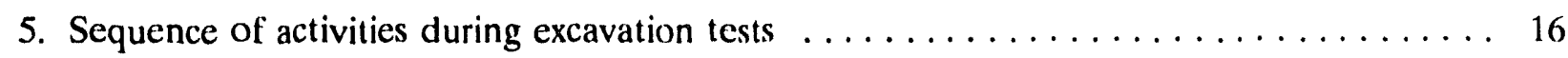

6. INEL cold test pit $\ldots \ldots \ldots \ldots \ldots \ldots \ldots \ldots \ldots \ldots \ldots \ldots \ldots \ldots \ldots \ldots \ldots \ldots \ldots$

7. Retrieval cells of the cold test pit $\ldots \ldots \ldots \ldots \ldots \ldots \ldots \ldots \ldots \ldots \ldots \ldots \ldots \ldots$

8. Location of cold test pit area $\ldots \ldots \ldots \ldots \ldots \ldots \ldots \ldots \ldots \ldots \ldots \ldots \ldots \ldots \ldots$

9. Access road to cold test pit area $\ldots \ldots \ldots \ldots \ldots \ldots \ldots \ldots \ldots \ldots \ldots \ldots \ldots \ldots$

\section{TABLES}

1. Data quality objectives $\ldots \ldots \ldots \ldots \ldots \ldots \ldots \ldots \ldots \ldots \ldots \ldots \ldots \ldots \ldots \ldots$

2. RWMC and BWID emergency contacts $\ldots \ldots \ldots \ldots \ldots \ldots \ldots \ldots \ldots \ldots \ldots$ 


\section{ACKNOWLEDGMENTS}

The efforts of all members of the Buricd Waste Robotics Program were required to successfully complete the Remote Excavation System Test Plan.

The authors wish to thank Barry Burks, Stephen Killough, and David

Thompson from Oak Ridge National Laboratory, Jon Pence from Lawrence Livermore National Laboratory, Dan Horschel from Sandia National

Laboratory, and John Morrison at the Idaho National Engineering Laboratory for their contributions to this report. 


\section{ACRONYMS}

BWID Buried Waste Integration Demonstration

BWRP Buried Waste Robotics Program

CERCLA Comprehensive Environmental Response, Compensation, and Liability Act

CX Categorical Exclusion

DOD Department of Defense

DOE Department of Energy

DOE-ID Department of Energy, Idaho Operations Office

DOE-HQ Department of Energy, Headquarters

EC Environmental Checklist

EDF Enginecring Design File

ER Environmental Restoration

ERD-SMO Environmental Restoration Department-Sample Management Office

FEMP Fernald Environmental Management Program

GPS Global Positioning System

INEL Idaho National Engineering Laboratory

I.LNL Lawrence Livermore National Lahoratory

MSDS Material Safety Data Sheet

NEPA National Environmental Policy Act

ORNL Oak Ridge National Laboratory

OSHA Occupational Safety and Health Administration

OTD Office of Technology Development

PM Program Manager

PMP Project Management Plan

PNL Pacific Northwest Laboratorics 


$\begin{array}{ll}\text { QPP } & \text { Quality Program Plan } \\ \text { RCS } & \text { Remote Characterization System } \\ \text { RES } & \text { Remote Excavation System } \\ \text { RTDP } & \text { Robotics Technology Development Program } \\ \text { RWMC } & \text { Radioactive Waste Management Complex } \\ \text { SDA } & \text { Subsurface Disposal Area } \\ \text { SNL } & \text { Sandia National Laboratorics } \\ \text { SPCC } & \text { Spill Prevention Control and Counter Measures } \\ \text { SWP } & \text { Safe Work Permits } \\ \text { TTP } & \text { Technical Task Plan } \\ \text { USID } & \text { Uranium Soils Integrated Demonstration }\end{array}$




\section{Remote Excavation System Test Plan}

\section{INTRODUCTION}

Excavation is the first step in the overall retrieve and treat option for remediation of buried waste. Conventional excavation of hazardous waste involves risks to operators that can be resolved by the use of robotic and teleoperated equipment. The Remote Excavation System (RES) (Figure 1) is a telcoperated excavator with an advanced control station that provides the following advantages over conventional excavation equipment:

- Safety is increased by removing workers from potentially hazardous waste sites (before and during removai of soil overburden and excavation of wastes)

- Precision of excavation is increased with the control software developed for the RES

- Operator efficiency is increased by providing a comfortable environment for the operator and eliminating the need for protective clothing, respirators, etc.

This section provides an introduction to the test plan. Section 1.1 discusses the technology and provides background information. Section 1.2 addresses the scope of the test. Section 1.3 gives the purpose of the test and the test objectives. Section 1.4 identifies the technology agreement with BWID and USID.

\subsection{The RES Technology Description and Background}

The RES is a remotely controlled retrieval system that was developed as a joint program at Oak Ridge National Laboratory (ORNL). Components of the system were developed by participants at ORNL, Pacific Northwest Laboratories (PNL), and Lawrence Livermore National Laboratory (LLNL). The end effectors developed originally for the system include a front end loader and a backhoe, which were controlled manually from within the cab of the vehicle. Remote control capabilities for the RES were developed at ORNL to provide a safe method of retricving buried materials, such as hazardous and radioactive wastes.

\subsection{Scope of Tests}

The RES was developed to provide remote excavation of waste forms on a buried waste site. The tasks covered in this document are the testing, evaluation, and demonstration of the various systems of the RES and the ability of the RES to retrieve buried waste at the INEL cold test pit for the BWID Program. Demonstration of the soil skimming capabilities of the RES for the Uranium Soils Integrated Demonstration (USID) at the INEL are also included in this test plan. In order, these tests include (1) preliminary equipment tests at ORNL, (2) open-air removal of overburden in layers from the retrieval cells of the INEL cold test pit, and (3) waste retrieval from the cold test pit retrieval cells in a temporary enclosure with contamination control methods. The test objectives are listed in Section 1.3.2. Brief descriptions of the tests can be found in Section 3, and detailed test procedures and sequences are discussed in Appendix A. The objectives for the RES tests were set up to provide both qualitative and quantitative data on the system and system components for DOE Environmental Restoration to use as input into the 


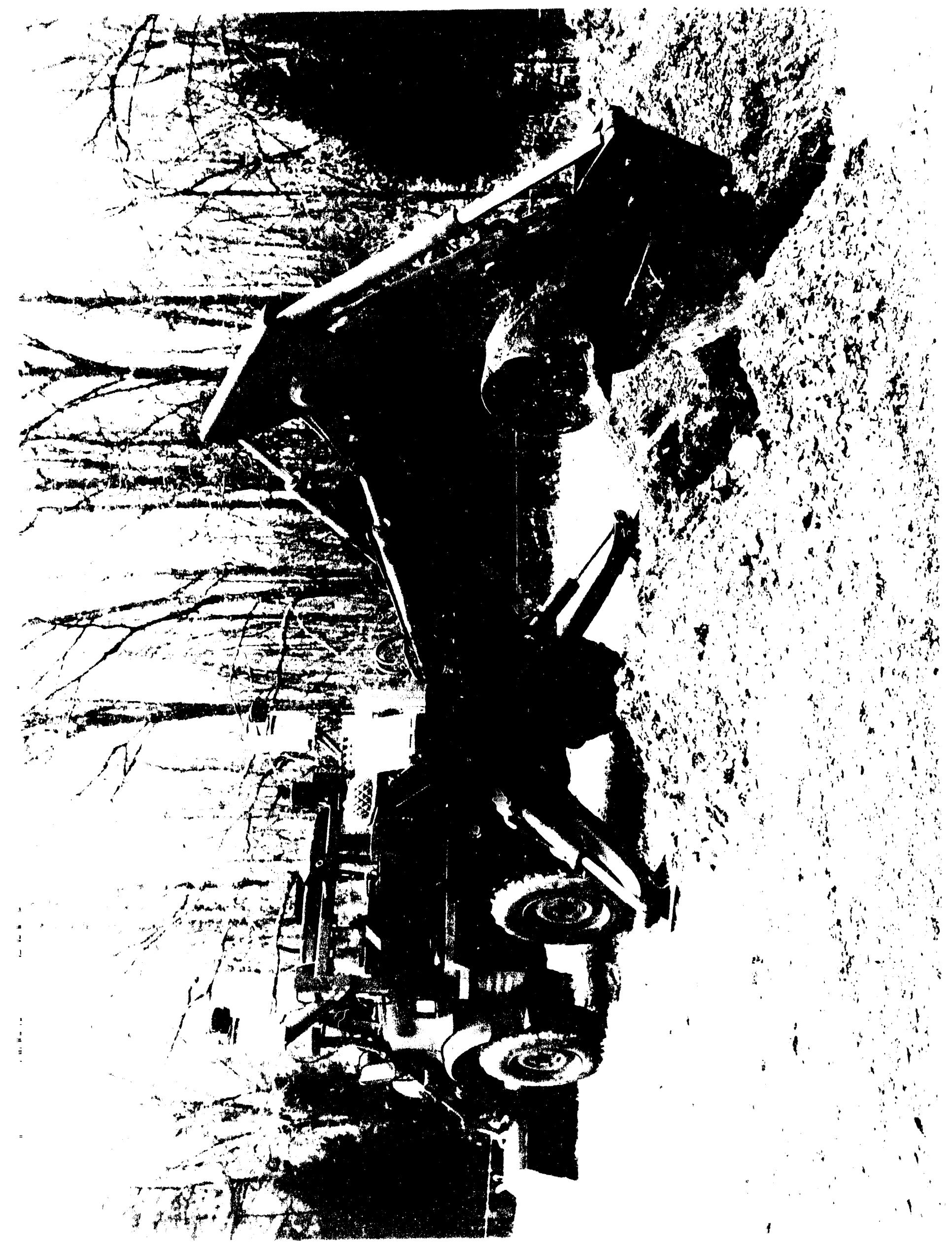


Comprehensive Environmental Response, Compensation and Liability Act (CERCLA) process or remediating buried waste sites.

\subsection{Purpose and Objectives of Test}

The purpose of this project is to test and demonstrate the capabilities of the excavation system and of the remotely-operated controls. The tests will be divided into two categories: (1) system performance test objectives and (2) component performance test objectives. The overall product will include test data on a mechanism to retrieve buried waste and an advanced control system that is applicable to various types of remote excavation. Some tests will be performed at ORNL and some at the INEL cold test pit.

The INEL cold test pit was designed to simulate buried waste configurations that may be encountered during retrieval of waste at various DOE sites. The purpose of performing the demonstration at the cold test pit is to evaluate use of the various elements of the RES during actual retrieval of buried waste.

\subsubsection{System Performance Test Objectives}

The RES has the following system test objectives based on BWID demonstration requirements: ${ }^{1}$

- Demonstratc the feasibility of remote excavation of buried waste, including waste containers and large buried objects

- Evaluate the system's ability to skim layers of soil

- Compare remote and manual performance of the backhoe in retrieving buried waste

- Provide input into the Environmental Restoration (ER), CERCLA process, for consideration for the Records of Decision and Safety Analysis for buried waste Operable Units

- Measure the spread of nonhazardous tracers during open-air soil skimming operations at the code test pit that occur during testing. Develop further understanding of the expected spread of contamination from actual retrieval operations at an INEL TRU waste pit

- Monitor and record the effects of the environment of the INEL Radioactive Waste Management Complex (RWMC) on the system

- Determine waste retrieval and overburden removal rates using the RES at the cold test pit

- Demonstrate the ability of the vehicle to transfer waste to $4 \times 4 \times 8 \mathrm{ft}$ boxes.

- Record and evaluate any system failures. 


\subsubsection{Component Test Objectives}

In addition to testing the overall system, several individual components of the RES will be tested. Following are the test objectives for the RES components. Note that the location where the tests will be performed are shown in parentheses. Procedures for taking data to satisfy these test objectives can be found in Appendix A. Testing the components of the RES is particularly important for future use by DOE Environmental Restoration (ER) of the technologics that comprise the RES.

\subsubsection{Control System.}

- Usability of the high-level control station (human factors analysis) (INEL)

- Operator control over vehicle speed

- Operator control over vehicle mancuverability (tracking)

- Ease of operation

- Quality of vicwing screens

- Performance of controls

- Uscfulness of displays

- Control over camera positions/adequacy of views (INEL)

- Identify factors affecting performance during testing (ORNL, INEL)

- Identify any deficiencies that appear during testing (ORNL, INEL).

\subsubsection{Camera System.}

- Evaluate the adequacy of cameras (ORNL)

- Ficld of view (zoom) and number of vicws

- Clarity (focus)

- Depth perception/target recognition

- Maximum range

- Camera placements for best viewing angles

- Capability in low light and sunlight (for viewing into excavation site)

- Determine the adequacy of the video switch (ORNL)

- $\quad$ Noise

- Quality of viewing resulting from switch

- Evaluate environmental effects (dust, etc.) (ORNL, INEL).

\subsubsection{Data Communications System.}

- Distance hetween controls and vehicle to loss of communications (INEL)

- Evaluate reliability (dead spots) (INEL) 
- Evaluate electromagnetic incompatibilities that occur during testing (ORNL, INEL)

- Identify additional facturs affecting system performance or any problems that occur during testing (ORNL, INEL).

\subsubsection{Small Emplacement Excavator.}

- Qualitatively compare the vehicle traction in different soil conditions (ORNL, INEL)

- Measure fuel consumption (INEL)

- Record the frequency and severity of maintenance (INEL)

- Identify strengths and weaknesses of the vehicle that become apparent during testing (ORNL, INEL)

- Identify factors affecting performance that surface during testing (ORNL, INEL).

\subsubsection{Backhoe.}

- Identify factors affecting performance that surface during testing (ORNL, INEL)

- Evaluate the ability of the force feedback system to prevent engine overloading (INEL).

\subsubsection{Front End Loader.}

- Identify factors affecting performance that surface during testing (ORNL, INEL).

\subsubsection{Global Positioning System.}

- Determine the system accuracy (real-time and processed) (ORNL)

- Determine the system precision (real-time and processed) (ORNL)

- Evaluate the system's reliability (INEL)

- Evaluate environmental effects (ORNL, INEL).

\subsection{Technology Agreement}

The RES was developed jointly by the DOD and the DOE, through the RTDP BWRP. The BWID and USID program are funding the demonstration, testing, and evaluation of the RES under TTPs ID-3320-(04, RL-3320-17, OR-1320-14, AL-2320-07, SF-2320-02, and ID-4310-01. 


\section{ORGANIZATION AND RESPONSIBILITIES}

\subsection{Organization Chart}

Figure 2 shows the organizational structure for BWRP, BWID, and USID.

\subsection{Description of Organizations}

Following is a description of the BWRP organization and the BWID Program organization.

\subsubsection{Buried Waste Robotics Program (BWRP)}

The BWRP consists of participants from ORNL, INEL, LLNL, PNL, SNL and FEMP. ORNL is the lead laboratory for the development of the RES and the INEL is the lead laboratory for performing the demonstration for BWID and USID.

\subsubsection{Buried Waste Integrated Demonstration (BWID) Program}

The mission of the BWID program is to demonstrate, test, and evaluate technologies that are potentially faster, better, cheaper, and/or safer for restoring buried waste sites. BWID will coordinate demonstrations that are intended to benefit the entire DOE complex by showing the capabilities of a remotely-controlled system to safely retrieve hazardous materials from the ground. At the INEL, BWID will also supply support facilities and utilities, as well as a demonstration coordinator for the RES and other demonstrations in June 1993.

\subsubsection{Uranium Soils Integrated Demonstration (USID) Program}

The mission of the USID program is similar to that of the BWID program. Its goal is to demonstrate, test, and evaluate technologies that will assist in the remediation of soils contaminated with uranium. USID is interested in the ability of the RES to remotely and precisely skim contaminated soils and is funding this portion of the demonstration of the RES at the INEL in June 1993.

\subsection{Personnel Support}

The Program Manager (PM) at each facility will be responsible for personnel support requirements during testing at their own facilities. The information below covers support requirements at the INEL demonstration. At the INEL, a BWID demonstration coordination manager will have the ultimate responsibility in decisionmaking during the demonstration. Should a safety concern arise, he and the safety engineer would decide how to solve the problem or to shut the tests down. If the RES tests at the INEL take longer than planned, the BWID demonstration coordination manager will have the authority to cut off further testing.

ORNL personnel will operate the RES. Their main responsibilities will be to operate the equipment from the control station, to monitor the data displays, and maintain the RES equipment. An experienced INEL backhoe operator will perform the manual excavation in a bubble suit. 
BWID DOE-HQ

PROGRAM MANAGER JAFFER MOHUIDDIN

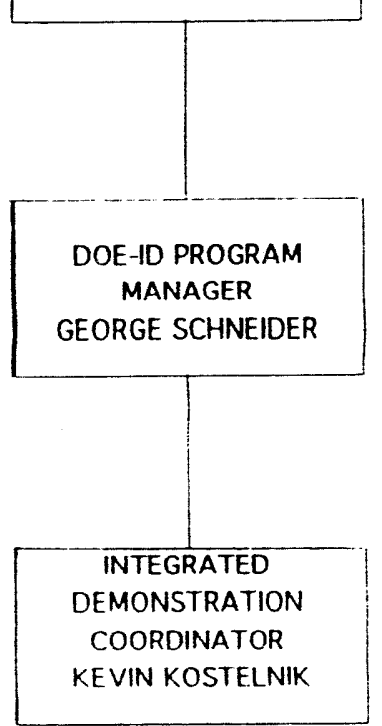

RTDP DOE-HQ PROGRAM MANAGER LIN YARBROUGH

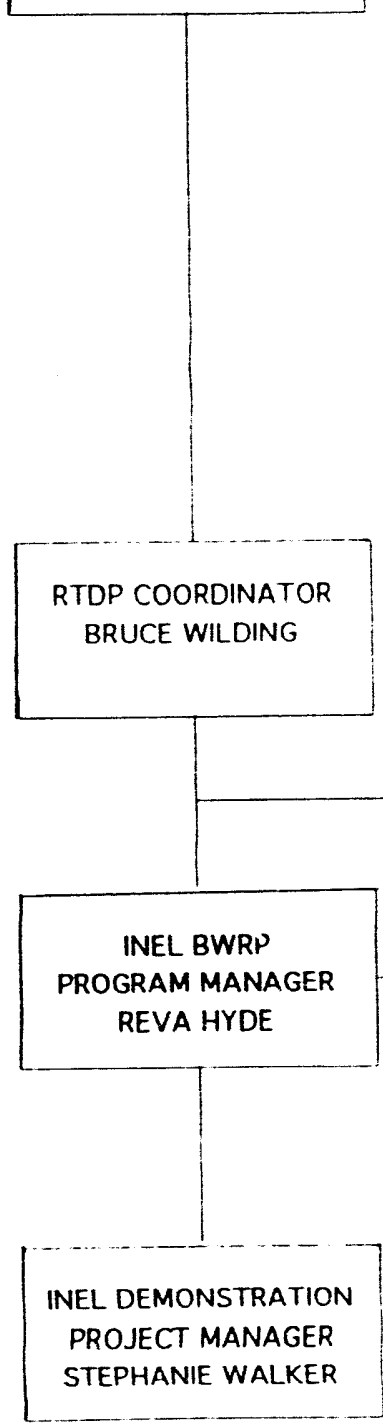

USID DOE-HG

PROGRAM MÄNAGE MIKE MALONE

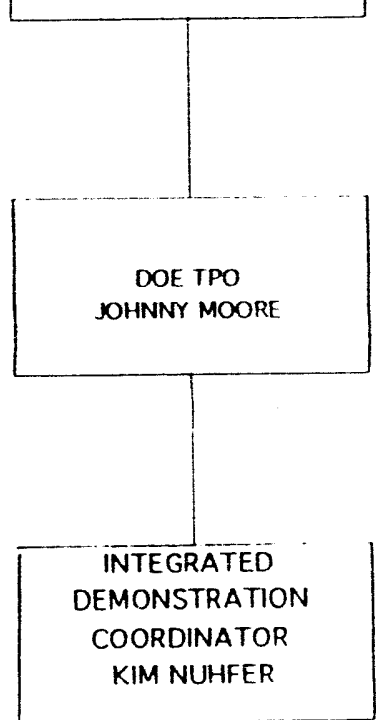

ORNL BWRP

PROGRAM

MANAGER

BARRY BURKS
PROGRA ".

MANAGER

DAN HORSCHEL
LLNL PROGRAM MANAGER JON PENCE

Figure 2. Organizational structure. 
The RWMC response team will be responsible for responding to any emergencies related or unrelated to the RES tests.

The INEL demonstration manager will be responsible for ensuring that all of the appropriate tests are conducted in accordance with the procedures identified in this test plan. She will also coordinate activities to ensure that data logbooks are completed properly, coordination of any field changes and media events, and coordination of photography and video production.

Topographical surveys will be performed by licensed INEL surveyors.

The INEL BWRP PM will be responsible for coordinating all the laboratories and visitors. She will also be responsible for coordinating any audits.

The BWRP PM from ORNL will be responsible for keeping the BWID demonstration coordinator informed on the status of the RES during the demonstrations. He will coordinate any activities associated with maintenance of the system. He will also be responsible for evaluating the data received during startup of the RES testing to verify that no obvious problems in the system have been incurred during setup. The main personnel supporting this task are listed in Table 1 below.

\subsection{Organizational Responsibilities-Chart}

Figure 3 depicts the test responsibilities matrix for the RES testing.

Table 1. Data quality objectives (see Appendices A and B).

\begin{tabular}{|c|c|c|c|c|c|}
\hline Measurement parameter & $\begin{array}{c}\text { Number of } \\
\text { samples }\end{array}$ & $\begin{array}{l}\text { Statistical } \\
\text { parameter }\end{array}$ & $\begin{array}{l}\text { Precision }^{\mathrm{a}} \\
(95 \%)\end{array}$ & Accuracy & Completed \\
\hline Retrieval rate & 11 & $\begin{array}{l}\text { Variance } \\
\text { Bias }\end{array}$ & $\mathrm{X} 1.5$ & $\pm 30 \mathrm{sec} / \mathrm{drum}$ & $100 \%$ \\
\hline Overburden removal survey & 4 & $\begin{array}{l}\text { Variance } \\
\text { Bias }\end{array}$ & $\mathbf{X} 40$ & $\pm 1 \mathrm{ft}$ & $100 \%$ \\
\hline Tracer spread & 6 & $\begin{array}{l}\text { Variance } \\
\text { Bias }\end{array}$ & $\mathrm{X}^{3}$ & $\begin{array}{l}<\times 10 \\
\text { background } \\
\text { level (to be } \\
\text { determined } \\
\text { during tests) }\end{array}$ & $100 \%$ \\
\hline
\end{tabular}

a. Within a $95 \%$ confidence the variance (precision) measured from the sample points will be no greater than the correction factors shown. 


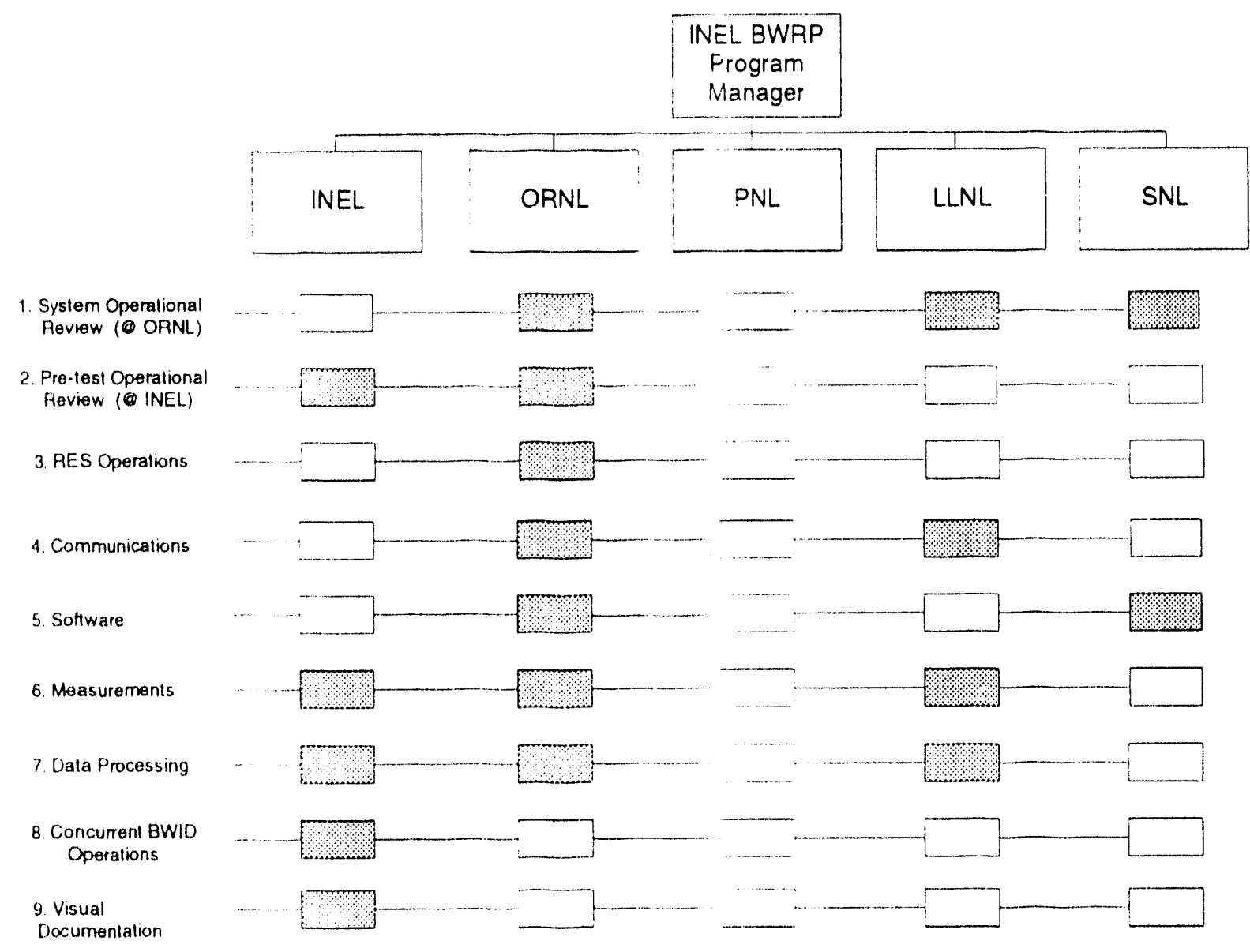

RES Test Matrix Responsibilities

Figure 3. RES test matrix responsibilities. 


\subsection{Responsibilities of each National Laboratory}

The responsibilities of the personnel at each national laboratory involved in the testing of the RES are listed below. The PM of each respective laboratory has the responsibility for all tests listed below.

\subsubsection{ORNL Test Responsibilities}

The ORNL BWRP PM is responsible for performing the following activities:

- Operate the RES during testing at ORNL and at the INEL cold test pit, or train an operator, if necessary

- Record any equipment failures or inadequacies during testing at ORNL and INEL to evaluate the system's reliability. Also record the availability of satellites at each location and evaluate the performance of the GPS inside the temporary structure at the INEL

- Record any previously undefined strengths of the system during testing at PNL, ORNL, and INEL

- Perform testing at the INEL cold test pit to remove overburden and retrieve the simulated waste

- Perform a system readiness review at $\mathrm{ORNL}$

- Identify and evaluate interference from other radios and equipment that occurs during testing at ORNL and INEL.

- Identify factors that affect performance of the control system and the data communications system during testing at ORNL and INEL

- Identify and evaluate any deficiencies in the overall system that become apparent during testing at ORNL and INEL

- Evaluate any environmental effects on the control system and the data communications system during testing at ORNL and INEL

- Assist INEL personnel in the human factors evaluation of the control system at the INEL

- Evaluate the adequacy of the computer software during testing at ORNL and INEL, recording any deficiencies in logbooks.

\subsubsection{INEL Test Responsibilities}

The INEL demonstration manager is responsible for the following activities:

- Record environmental conditions at the INEL cold test pit duing testing and assist in recording environmental effects on the equipment during the demonstration 
- Perform a human factors evaluation of the control system at the INEL

- Record the time to remove overburden and waste containers from the INEL cold test pit, and the time to process and evaluate these data

- Supfort and assist ORNL in testing at the INEL as requested

- Supply technicians for testing support at the INEL

- Handle any issues related to testing at the INEL during the demonstration, such as safety, disposal, utilities, transferring data, etc.

- Record fucl used by the vehicle during the INEL tests and calculate fuel efficiency of the vehicle

- Record any maintenance that is performed during the INEL demonstration and the time for the operation

- Measure the amount of rare earth tracer spread during overburden removal

- Perform a topographical survey of the site between layers of overburden

- Coordinate the video production.

\subsubsection{SNL Test Responsibilities}

- Evaluate and critique the adequacy of the data displays

- Assist ORNL personnel in the identification and evaluation of any deficiencies in the overall system that become apparent during testing at ORNL and INEL.

\subsubsection{LLNL Test Responsibilities}

The LLNL demonstration manager at the LLNL is responsible for the following tests:

- Monitor and evaluate the video and data telemetry links of the RES.

\subsection{Qualifications and Training Required}

All personnel operating equipment will he properly trained to operate the equipment. OSHA and blue card training requirements are discussed in Section 12.2. The bubble suited operator will have respirator training and be an experienced backhoe operator. Any additional qualifications required for operation of various equipment (Control System, GPS, data processing, etc.) will be specified in the individual operating procedures. 


\section{DESCRIPTION OF TESTS}

\subsection{System Performance Tests}

Tests on the RES will be performed at ORNL and the INEL. This section covers testing at all of these facilities. Figures 4 and 5 contain block diagrams of test activities that will be performed at the INEL. General descriptions of each test are given below; test procedures are included in Appendix A. All test results will be provided in a technology evaluation report.

\subsubsection{BWID Test Requirements}

Demonstration of the RES at the INEL cold test pit will include removing overburden with the front loader and the backhoe and retricving waste from the pit with the backhoe. This demonstration will be performed to meet the following test objectives for BWID:

- $\quad$ Demonstrate the feasibility of remote excavation of buried waste. This objective will be met by remotely excavating portions of the INEL cold test pit with the RES. The resulting data will include a video tape of the excavation and recorded retricval rates for remote excavation.

- Compare remote and manual performance of the backhoe in retrieving buried waste. This objective will be achieved by operating the excavator manually to excavate portions of the pit, and comparing the retricval rate with the rate for remote excavation. Manual excavation will be performed in the manner in which actual retrieval operations are performed, with the operator in a bubble suit using a respirator. The rates for both manual and remote retrieval will be measured per the procedures in Section A-6 of Appendix A.

- Help provide input into the ER CERCLA process for consideration for the Records of Decision and Safety Analysis for buried waste operable units. This is the goal of all RES testing, and will be met by the video tape of the demonstration, computer disks containing testing data gathered during testing, and a Technology Evaluation Report containing the test results.

- Monitor the environmental effects on the system. The weather conditions at the RWMC will be measured during RES testing, and any effects of the environment on the system will be noted in the logbooks for later analysis. Wind speed, wind direction. temperature, relative humidity, and barometric pressure will he recorded by the National Occanic and Atmospheric Administration. In addition, any noticeable effects of the contamination control system on the RES will be recorded in the loghooks.

- Determine waste retrieval and overburden removal rates at the cold test pit. Waste retrieval rates will be calculated by measuring the volume retrieved and the time to perform the operation and will be reported in $4 \times 4 \times 8 \mathrm{ft}$ boxes per hour and $\mathrm{ft}^{3} \mathrm{hr}$. These rates will also be used to compare remote and manual excavation, as discussed above. Overburden removal rate will be measured in the same way and reported in $\mathrm{ft}^{3} / \mathrm{hr}$. 


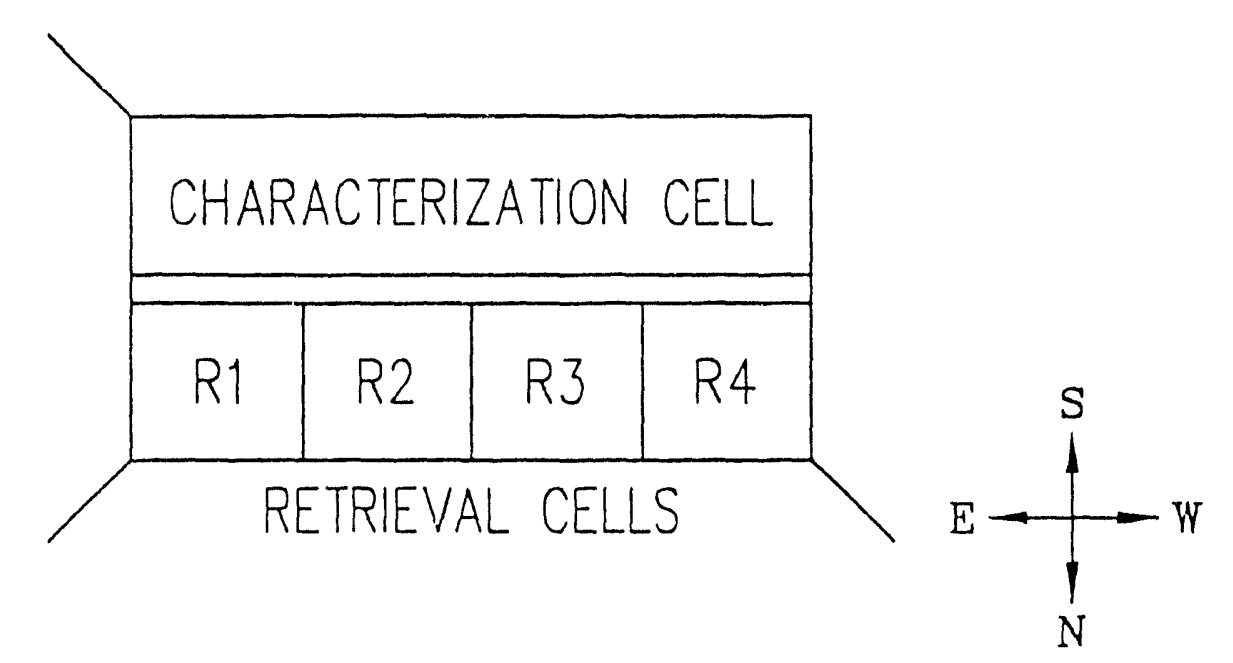

1. EXiAVATOR MLL BE FLICED CN THE RETREVAL CELLS

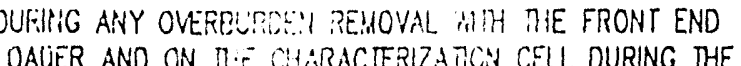
REST OF THE DEMCISTRR: IONS.

2. OURING RETREVYL, SOLL AND SIMULATEO WASTE MLL BE PLACEO INTO 4' $4^{\prime} 4^{\prime} \times 8^{\prime}$ ' BOXES. CLEAN SOIL WL BE PCACD ITS $x$. CONTAINERS MLLL BE DISPOSED OF IN A SANITARY LANOFILL.

3. ALL OPERATIONS WLL BE PERFORMED REMOTELY, UNLESS OTHERMSE NOTED.

4. SLOFFO SIDES ON THE EAST \& "HEST ENDS OF THE RETRIEVAL CELL MilLL BE PREPARED OURING OVERBURDEN REMOVEL TO PROMDE ACCESS TO TIE PIT FOR THE RCS.

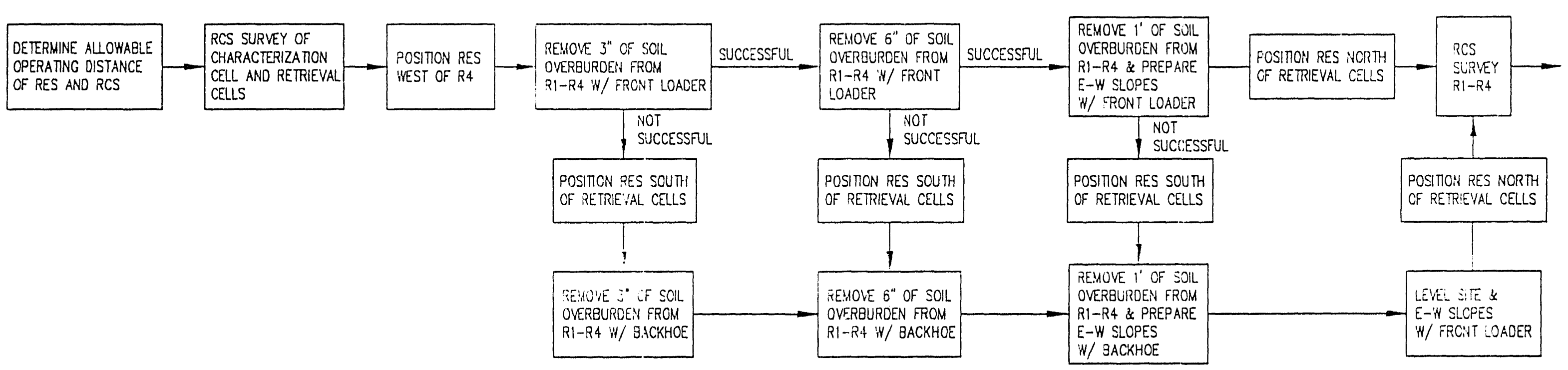

\begin{tabular}{|c|c|c|c|c|c|c|c|c|c|c|c|c|}
\hline $\begin{array}{l}\text { RENOVE I' OF } \\
\text { OVEREURDEN } \\
\& \text { PREPARE E-W } \\
\text { SLOPES W/ BACKHOE }\end{array}$ & $\begin{array}{l}\text { LEVEL SITE \& } \\
\text { E-W SLOPES } \\
\text { W/ FRONT } \\
\text { LOADER }\end{array}$ & $\begin{array}{l}\text { RCS } \\
\text { SURVEY } \\
\text { R1-R4 }\end{array}$ & $\begin{array}{l}\text { IF TME, } \\
\text { SURVEY } 1988 \\
\text { COL TEST PIT }\end{array}$ & $\begin{array}{l}\text { RCS DEMONSTRATION } \\
\text { COMPLETE }\end{array}$ & $\begin{array}{l}\text { POSITCN RES } \\
\text { HORTH OF } \\
\text { RETREVAL } \\
\text { CELLS }\end{array}$ & $\begin{array}{l}\text { REMOVE } I^{\prime} \text { OF } \\
\text { OVERBURDEN } \\
\text { FROM RI-RA } \\
\text { W/ BACKHOE }\end{array}$ & $\begin{array}{l}\text { POSITION RES } \\
\text { NORTH OF } \\
\text { RETRIEVAL } \\
\text { CELLS }\end{array}$ & \begin{tabular}{|l|} 
REYOOVE $6^{*}$ OF \\
OVERBURDEN \\
FROH R1-R4 \\
W/ BACKHOE
\end{tabular} & \begin{tabular}{|l|} 
POSITION RES \\
NORTH OF \\
REIRIEVAL \\
CELS
\end{tabular} & $\begin{array}{l}\text { REMOVE 3" OF } \\
\text { OVE:BSURDEN } \\
\text { FRCA R1-R4 } \\
\text { W/ :ACKHOE }\end{array}$ & $\begin{array}{l}\text { SCLL } \\
\text { SKIHMNING } \\
\text { OEMCNSTRAIIIN } \\
\text { COMPLETE }\end{array}$ & -1 EXCAVA \\
\hline
\end{tabular}


1. EXCAVATOR WLL BE PLACED ON THE RETRIEVAL CELLS DURING ANY OVERBURDEN REMOVAL WITH THE FRONT END LOAUER AND ON THE CHARACTERIZATION CELLL DURING TIE
REST OF THE DEMONSTRATIONS.
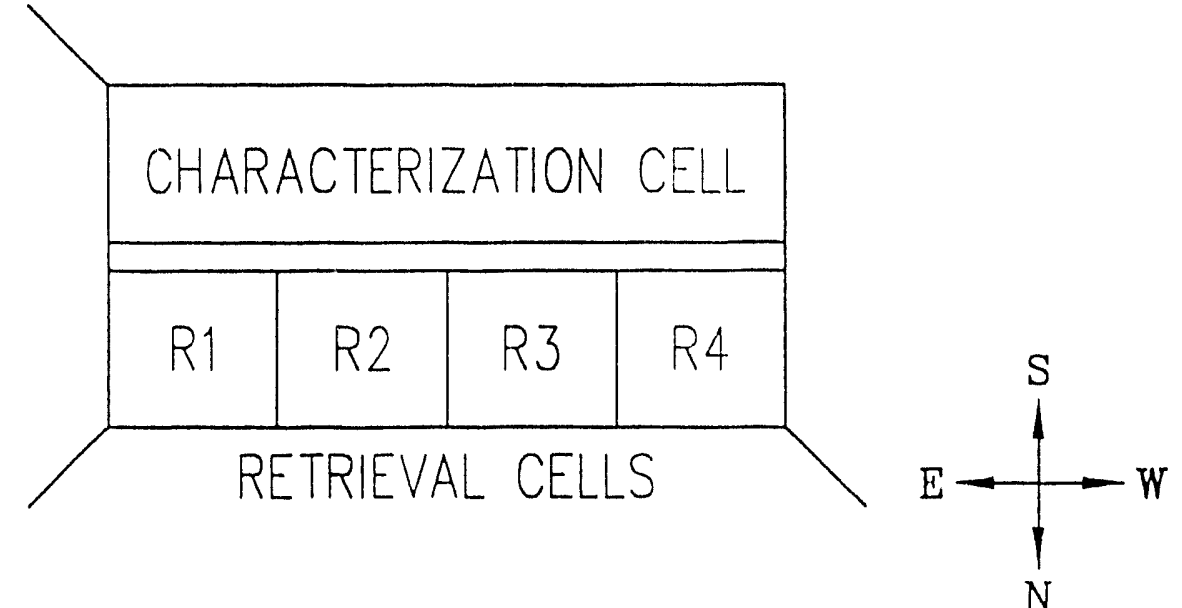

2. DURING RETRIEVAL, SOLL AND SIMULATED WASTE WLL BE PLACED INTO $4^{\prime} \times 4^{\prime} \times 8^{\prime}$ BOXES. CLEAN SOLL WLL BE SIMULATED WASTE AND ANY SOLL WTH DEBRIS FROM BREACHED CONIANERS WL BE DISPOSED OF IN A SANITARY LANDFLL.

3. ALL OFERATONS MLL EE PERFORMED REMOTELY, UNLESS

4. SLOPED SIDES ON THE EAST \& WEST ENDS OF THE RETRREVAL CELL WLL BE PREPARED OURNG OVERBURDEN REMOVEL TO

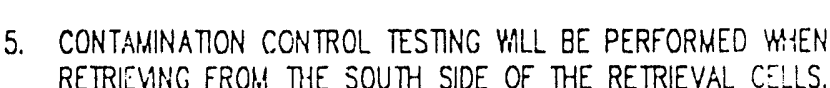
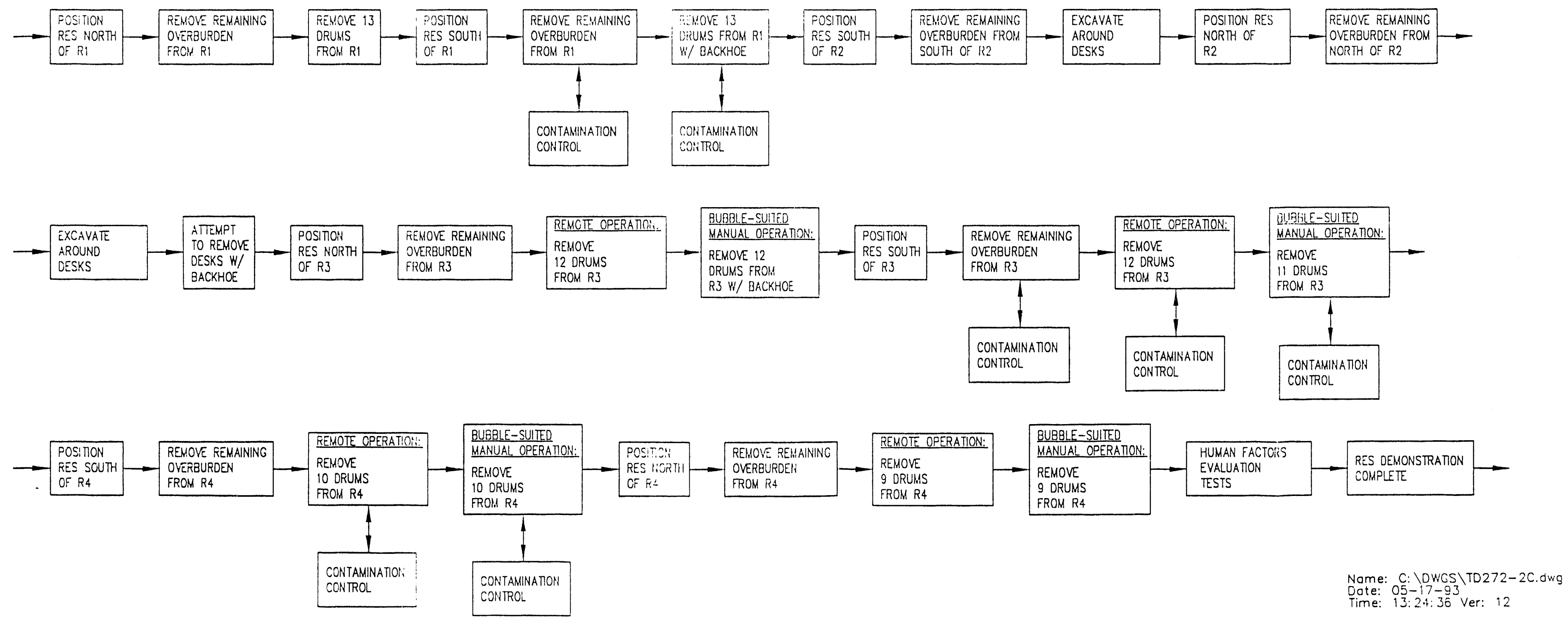

Figure 5. Sequence of activities during excavation tests. 
- Demonstrate the ability of the RES to transfer waste to boxes. This objective will be met by recording the front end loader and the backhoe dumping soil and/or waste into $4 \times$ $4 \times 8 \mathrm{ft}$ boxes on video tape. A qualitative evaluation of the RESs ability to transfer waste into the boxes will be included in the Technology Evaluation Report.

- Record and evaluate any system failures. Any system failures or inadequacics observed during the demonstration will be recorded in the logbook and evaluated in the final report.

\subsubsection{USID Test Requirements}

The objectives for the USID portion of the tests are as follows:

- Determine the ability of the RES 10 skim layers of soil to within a specified precision. The ability of the RES to preciscly skim layers of soil will be tested by removing 3 in., 6 in., and 1 ft from the retrieval eclls of the INEL cold test pit. After each layer of soil is removed, a topographical survey will he performed to determine the precision and accuracy of the RES in soil skimming. Both the front end loader and the backhoe will be tested to meet this objective. The front loader was not designed for excavation, but for loading and moving loose materials. However, removing only a few inches of topsoil may be possible with the front loader and will be tested. Retrieval rates will also be calculated. The procedures for this test are in Sections A-2 and A-6 of Appendix A.

- Evaluate the spread of rare earth tracers through dust generation during soil skimming operations. Rare carth tracers will he placed in the overburden of the retrieval cells. During skimming, these tracers will be released into the air, attached to dust particles. Air samplers will be used to determine the spread of the tracers resulting from skimming with the RES. This activity will simulate the spread of uranium contamination during actual retricval operations. The procedure for this test is in Section A-2 of Appendix A.

- Evaluate INEL/FEMP soil characteristics to estimate performance of the system in FEMP soils. A soil physicist will evaluate the INEL and FEMP soils, and translate the results of INEL tests to expected results at FEMP.

\subsection{Component Tests}

Much of the testing of RES components will he performed at ORNL. These tests, as well as any component tests that will be performed at the INEL, are described below. Detailed procedures on the tests outlined below are provided in Appendix A.

\subsubsection{Evaluate The Control System}

3.2.1.1 Usability of the Control Station. The usability of the high-level control station will be cvaluated with a human factors analysis. Below is a list of tasks that will evaluate the usability of the control station. Operator satisfaction (as discussed below) will be measured by using a subjective scale. Techniques for quantilying subjective judgements have heen developed in the field of psychometrics. Psychometric techniques are subjective measurement methods and have been used to subjectively measure a person's perception of mental workload, pereeption of 
quality, and for many other applications. There are two basic types of psychometric techniques; ranking and rating. Ranking is a method by which you order some list from lowest to highest or from highest to lowest preference. Rating is a method used to obtain some type of classifiable quantity. There are several types of rating scales, including (a) global or straight point scales such as bipolar and Likert scales; ${ }^{2}$ (b) global-guided or scales that use a network of questions that guide the evaluator to a point on a straight point scale such as Cooper-Harper scale; ${ }^{3}$

(c) multidimensional-global or scales that break down the subject into more detailed subparts and rate the subparts, such as the Subjective Workload Assessment Technique ${ }^{4}$ or Task Load Index: ${ }^{5}$ and (d) multidimensional-global-guided or scales that break down the subject into subparts, and rate those subparts using a global-guided scale. The scale to be used for measuring operator satisfaction will be a global-guided scale. This scale uses a flowchart to help structure the evaluation process. By doing this, the technique allows for a ten-point scale, which is more reliable that the traditional global five or seven point scale. Because humans typically can only distinguish between seven \pm two things," the method uses a flowchart that only requires humans to distinguish between two or three things at a time, but for several episodes-making it a tenpoint scalc. The scale is quick, easy to use, and requires minimal training. This technique has been proven to be sensitive, reliable, and valid. ${ }^{7}$ The global-guided scale is included in the test procedure in Appendix A. The tasks that will he evaluated include as follows:

A. Operator control over vehicle speed. Operator control over vehicle speed will be evaluated by operator satisfaction of the response of the vehicle to the pressure on the control stick. This will include operator satisfaction with the response time as well as speed control.

B. Operator control over vehicle manewverahility. Operator control over vehicle maneuverability will be cvaluated by operator satisfaction of the response of the vehicle to the pressure on the control and by evaluating the operator's ability to follow a specified path. This will include operator satisfaction with the response time as well as positioning control.

C. Ease of operation. Ease of operation lakes into account all operations including, but not limited to vehicle manipulation, eontrols, and displays. This type of test will be a qualitative judgement by operators. The learning curve for several operators will be plotted for comfort level of operating the RES versus time of operation. In addition, the actions of operators during a simulated emergency will be evaluated.

D. Quality of viewing screens. The quality of the viewing screens will be evaluated by measuring several parameters. The distance from which the operator views the screens, the size of the text, and the luminance levels, will be measured. In addition, operator comments on the screen layouts will he documented.

E. Peiformance of the controls. Performance of the controls will be qualitatively measured by operator satisfaction. The number of incorrect actions to perform a task will also be documented.

F. Usefulness of displays. The usefulness of the graphics screens will be qualitatively measured. This test will not only address operator satisfaction, but address the operators satisfaction with the real-lime data display. 
3.2.1.2 Control Over Camera Positions. Control over the camera positions will be evaluated during the human factors analysis of the RES. The analysis will evaluate the response of the cameras to the pressure on the controls. This will include both operator satisfaction over the response time and positioning control. In addition, the satisfaction of operators for views provided by the cameras will be noted.

3.2.1.3 Identify Factors that may affect Performance. Testing and demonstration of the RES should reveal parameters and conditions that may affect the performance of the control system. Any conditions affecting the controls will be recorded in the logbooks and identified in the Technology Evaluation Report. Such factors may include the comfort of the chair, the lighting conditions, auditory interference, physical arrangement/layout, atmospheric conditions/control, and any safeguards.

3.2.1.4 Identify Any Deficiencies. Any deficiencies that appear in the control system during testing of the RES will be recorded in logbooks and identified in the Evaluation Report.

\subsubsection{Evaluate the Camera System}

Evaluation of the cameras, the location the cameras are mounted, and the video switch will be performed at the iNEL with the cameras installed on the RES.

3.2.2.1 Adequacy of Cameras. The adequacy of the cameras selected for the RES will be evaluated primarily at INEL. Camera placement, number of views, field of view for best viewing, clarity, depth perception, target recognition, minimum and maximum range, the capabilities of the pan and tilt, and the capabilities in low light and sunlight will be evaluated at the INEL cold test pit.

3.2.2.2 Video Switch. The effects of induced noise on the video switch and the quality of the switch during operation will be determined qualitatively at INEL by questioning operators about the adequacy of the switch.

3.2.2.3 Environmental Effects. Weather conditions at ORNL and the INEL are different and must be considered in the evaluation of the camera system. Any problems from dust, rain, or other condition will be recorded in logbooks and presented qualitatively in the technology evaluation report. Any other effects of the environment on the camera system observed during testing at ORNL and the INEL will also be recorded.

\subsubsection{Evaluate the Data Communications System}

Data are communicated between the on-board sensors and the control station by a radio frequency link. The data communications system will be evaluated at ORNL and the INEL.

3.2.3.1 Distance Between Controls and Vehicle to Loss of Communications. The maximum usable operating range of the data communication system will be tested over a flat, open terrain at the INEL. This distance will be defined at the point where the communications data system becomes dysfunctional. The operating range will be this distance with an administrative safety factor applied.

3.2.3.2 Reliability. System reliability of the data communications system will be evaluated qualitatively during the INEL demonstration. The reliability of the data communications system 
will be measured by recording the amount and frequency of lost data transmission measuring and recording any equipment failures or inadequacies.

3.2.3.3 Electromagnetic Incompatibilities. Interference from other radio equipment used during testing, such as radios for personnel communication is not expected, because different frequencies will be used for data communication and for all other activities. The frequencies used by the RES have been approved and reserved at ORNL and the INEL. Observed interferences during testing at each laboratory will be recorded in logbooks and evaluated. A frequency spectrum analyzer will be used at the INEL to find and evaluate any interference frequency sources that occur during testing.

3.2.3.4 Identify Additional Factors that may affect Performance. Any additional factors that may effect the performance of the data communications that are observed during testing at each laboratory will be recorded in logbooks and evaluated.

\subsubsection{Evaluate the RES Vehicle.}

The RES vehicle was designed and developed for the U.S. Army, and manual operation has been fully tested. Tests that will be performed to evaluate the vehicle are discussed below.

3.2.4.1 Vehicle Traction. The vehicle traction in the different soil types of the INEL and ORNL will be evaluated qualitatively by recording observations in the logbooks during testing at ORNL and the INEL.

3.2.4.2 Fuel Consumption. During the INEL demonstrations, the vehicle will be operated for long periods of time under conditions simulating waste site characterization. The amount of fuel used for the operations will be recorded in logbooks.

3.2.4.3 Frequency and Severity of Maintenance. The frequency and severity of all maintenance will be recorded during the INEL demonstrations. Operating the vehicle for an extended period of time will provide the most accurate calculation of maintenance costs.

3.2.4.4 Strengths And Weaknesses. Any previously undefined strengths and weakness of the vehicle that become apparent during testing will be recorded in logbooks.

3.2.4.5 Identify any Deficiencies. Any vehicle deficiencies that become apparent during testing at ORNL or the INEL will be documented in logbooks.

\subsubsection{Evaluate the Backhoe}

Testing of the backhoe is achieved during system performance tests at the INEL cold test pit. In addition, the following observations will be made at the cold test pit and noted in the logbooks.

- Evaluate the capabilities of the force feedback system

- Identify factors that may affect performance 


\subsubsection{Evaluate the Front End Loader}

Testing of the front end loader is achieved during system performance tests at the INEL cold test pit. Attempts will be made to remove soil overburden from the pit with the front end loader. The results of these attempts will be noted in the logbooks. In addition, factors that affect performance will be identified and noted in the logbooks.

\subsubsection{Evaluate the Positioning System}

The kcation of the vehicle will be determined by a Global Positioning System (GPS). The GPS used on the RES is the same system as that used on the Remote Characterization System (RCS). The GPS will undergo thorough testing for accuracy, precision, and reliability, as well as environmental effects on the system and the effects of postprocessing the data during testing at PNL. (See Test Plan for the RCS, EGG-WTD-107()4.) ${ }^{8}$

\subsection{INEL Cold Test Pit}

Figure 6 illustrates the cold test pit and Figure 7 shows the details of the retrieval cells that will be excavated during the demonstration tests. The retrieval cell of the test pit at the RWMC is $40 \mathrm{ft} \mathrm{long} .106 \mathrm{ft}$ wide, and approximately $10 \mathrm{ft}$ decp. There is a $6 \mathrm{ft}$ soil berm between the retrieval cell and the characterization cell. The retrieval cell is divided into four zones. Each zone is approximately $10 \times 10 \times 10 \mathrm{ft}$. Zone 1 is a random dump zone composed of $44 \%$ waste by fotal volume. The total waste volume is $25 \%$ cardboard and metal drums and $19 \%$ random objects such as cardboard boxes, metal objects, and concrete scrap. The area is $90 \%$ cardboard drums and $10 \%$ metal drums with half of the drums heing 55 gal and the other half $30 \mathrm{gal}$. Water will be poured over this area when it is completed to enhance the decomposition of the cardboard. Zone 2 is composed of two metal desks set together to constitute a single large metal object. It is in the center of the area and the orientation is known. Zone 3 consists of a random dump of metal drums. Half of the drums are $55 \mathrm{gal}$ and the other half are 30 gal. The zone is composed of $44 \%$ by waste volume. Zone 4 consists of horizontally stacked drums. The stack size is approximately $6 \times 6 \times 10 \mathrm{ft}$. Half of the drums are $55 \mathrm{gal}$ and the other half are $30 \mathrm{gal}$. The drums are composed of hoth cardboard $(90 \%)$ and metal $(10 \%)$. The Enginecring Design File (EDF) developed for construction of the cold test pit provides further details on the pit. ${ }^{9}$

\subsection{Uncertainty Analyses}

Uncertainty analyses will be performed for all measurements and lests relating to the RES system performance lests requested by BWID. Results will be documented in the Technology Evaluation Report.

The performance of the measurement systems must be evaluated. Two quantitative performance characteristics of a measurement system are the precision and the accuracy, and these both will be determined, either experimentally or by engineering judgment. They will be given for systems that affect any of the system test objectives discussed in Section 3.1. The precision and accuracy will be developed for the entire system, not merely for the individual components, and the operators will be considered part of the system.

The precision and accuracy of the measurement system will be estimated from test measurements, and both a hest estimate and a $95 \%$ contidence interval will be given for the precision and for the accuracy. In the event that a particular test is invalid for some reason or 


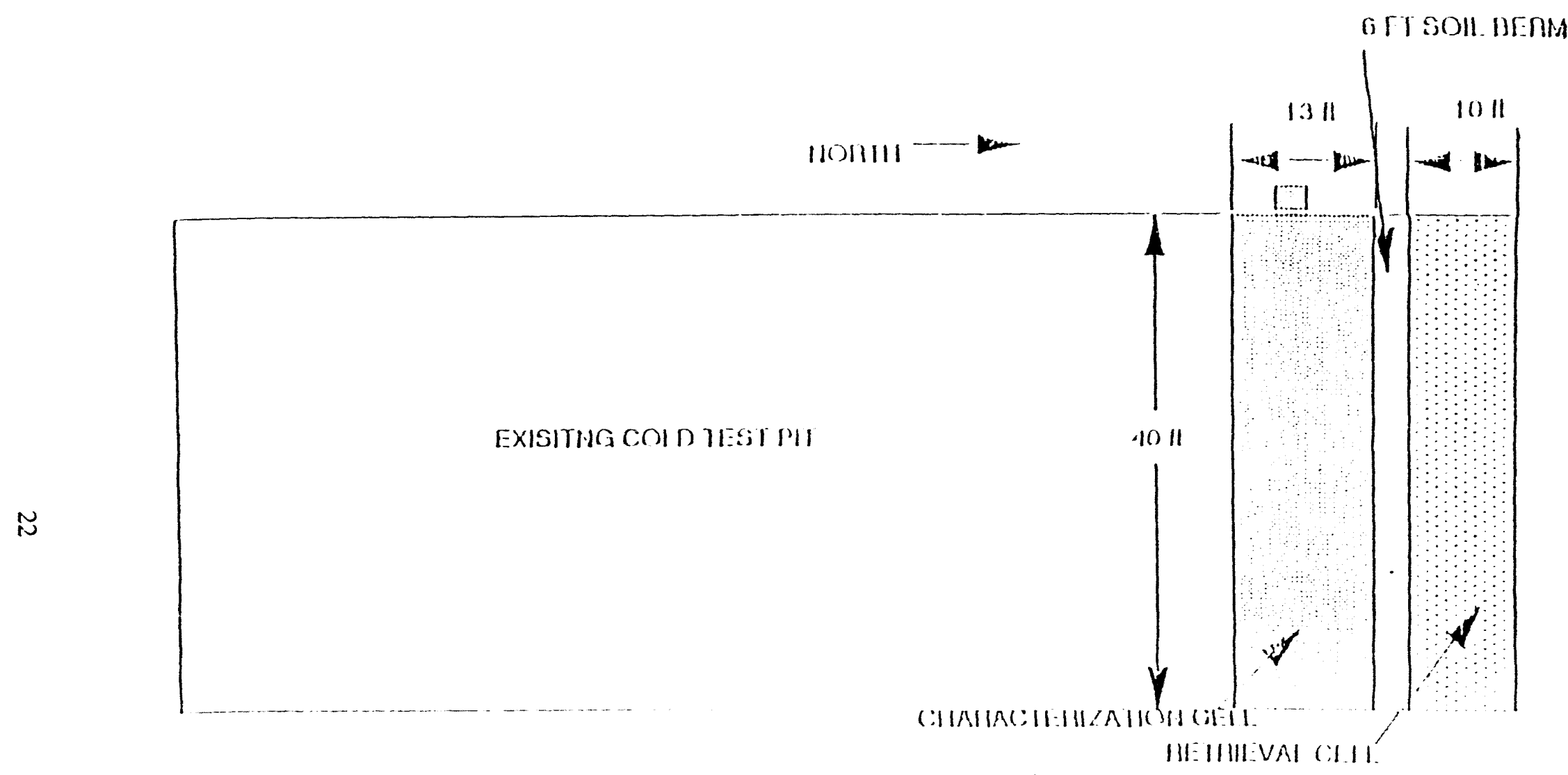

Figure 6. INEL cold test pit. ${ }^{9}$ 


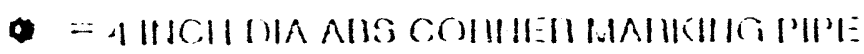

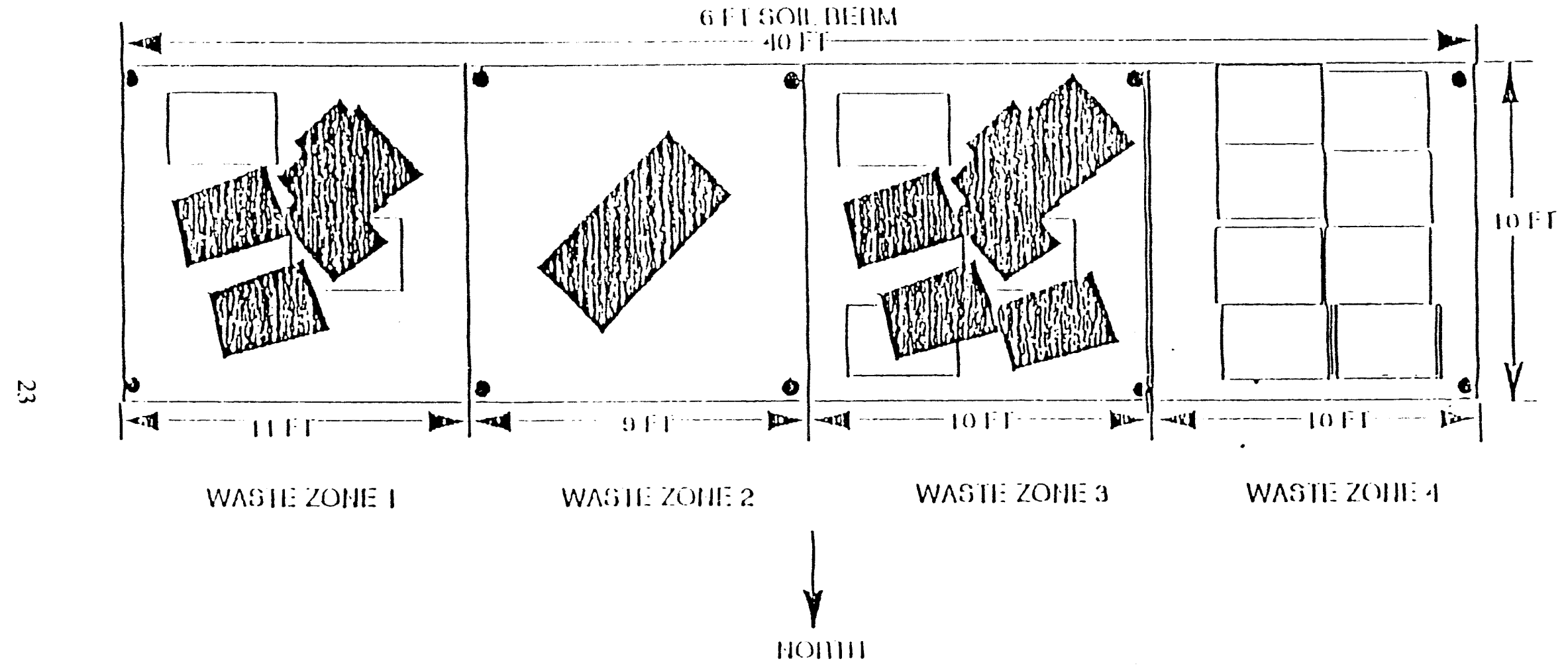

Figure 7. Retrieval cells of the cold test pit. ${ }^{9}$ 
the data are lost, best engineering judgement will be used to determine precision and accuracy of the system. This will be documented in the final report.

\subsection{Contingency Plan(s)}

Tests will be discontinued in the event of weather conditions that seriously affect testing (thunderstorms, high winds, etc.), unavailable GPS satellites, an equipment failure or an accident or emergency at the testing site. Approximately three days of contingency have been provided in the INEL schedule in case of such an event. At the INEL, the BWRP PMs and the BWID Demonstration Coordination Manager will evaluate the situation to determine the most appropriate method to meet the test objectives. The ORNL PM will perform the same evaluation during testing at ORNL. In the event that testing deviates from this test plan, the test procedures will be "red-lined" in the field and initialled by the ORNL PM and copies of these altered procedures will be provided to BWID within two weeks. Any "red-lining" of procedures at the INEL will be performed in accordance with BWID requirements for field changes in procedures for testing at the cold test pit.

If the RCS is not available for demonstration during the overburden removal portion of the INEL demonstration, RES testing will proceed as discussed in this test plan. If the Contamination Control Unit is not available for controlling dust generation during the excavation portion of the demonstration, water will be sprayed during the operation. An uncontrollable leak in the exhaust vent will require opening up the sides of the tent. 


\section{SEQUENCE OF ACTIVITIES}

Figures 4 and 5 depicted the sequence of activities during INEL tests. Contamination Control Unit and RCS testing are included on these flowcharts.

Test responsibilities will be performed at ORNL are listed below. All RES testing at ORNL will be completed by July 20 .

- Noting effects of ORNL environment on system-bright light, rain, or any other condition that causes unusual effects on the system

- Observe and record any electromagnetic interferences affecting the system during ORNL testing, including data and video communication or the GPS

- Observe and record any failures or inadequacies in the system that become apparent at ORNL that should be acidressed for further development or for consideration by ER. 


\section{SAMPLING AND DATA}

The overburden removal test includes the removal of three different controlled soil thicknesses over an area measuring $10 \times 40 \mathrm{ft}$. Layers of 3,6, and $12 \mathrm{in}$. shall be removed. The waste retrieval test involves removing 111 drums from the retrieval cells.

\subsection{Accuracy of Overburden Removal}

The actual depth for each cut shall be measured. The measurement will be attained manually at each point on a 30 point grid pattern as described in Appendix B. These data shall be recorded on a specially prepared form for later consolidation, Table A-1.

\subsection{Contamination Spread}

Particulate air samples shall be collected at strategic locations within and around the test area during overburden removal. Filter samples shall be collected from $47 \mathrm{~mm}$ low volume (LO-VOL) and high volume (HI-VOL) air samplers. Filters shall be changed out between each cut giving dust generation and contamination spread data for each of the 3-, 6-, and 12 -in. intervals. Test runs and air samples may be repeated at the discretion of the EG\&G representative to account for meteorological disturbances.

\subsection{Retrieval Rates}

Time studies shall be performed to determine the time rate of soil removal for each of the test runs and the time to retrieve the drums in each cell.

\subsection{Unusual Events}

Any unusual events shall be recorded in the test logbooks, by still photography, and/or video. An unusual event is any event not expected to occur during the tests. Examples of unusual events include, but are not limited to: equipment breakdowns, unique environmental conditions (such as rain), contacting waste while removing overburden, and operational problems with the design of the equipment, the processes, and procedures. 


\section{DOCUMENT CONTROL}

This section discusses document control. EG\&G Idaho procedures for document control will be followed for this project.

\subsection{Data Management}

\subsubsection{BWID Requirements}

Data will be managed to best protect the credibility of these data and is in compliance with the BWID PMP. In addition, the project shall comply to the following BWID data management policy:

Management of Electronic Data:

1. The project shall define the format, acquire the data, back up the data daily, control the configuration of the data, technically document the data, generate processed data, and archive the data.

2. The project shall submit to BWID a copy of all configuration controlled data (raw and processed) and appropriate technical documentation acquired during the course of the demonstration testing. Project shall submit complete copies of final configuration controlled raw and processed data with appropriate technical documentation to BWID with the final report.

Management of Reports:

1. The project shall draft reports, obtain and incorporate review comments, obtain approvals, archive, and control the configuration of data via a project Engineering Design File (EDF).

2. Copies of all draft reports shall be submitted to BWID. Copies of all final reports shall be submitted to BWID with an electronic copy.

Management of Logbooks:

1. Data shall be recorded in logbooks per EG\&G Idaho guidelines.

2. All logbook entries shall be photocopied at the end of each day of the demonstration, with copies delivered to BWID.

\subsubsection{Project File}

The project shall establish a project file (\#015547-1) that complies with all the requirements of the BWID program. The project file shall be a repository of all hard copy data (letters, reports, engineering analysis, etc.) and electronic copy, original and backup (data, processing software, etc.) information. The file shall have an index to configuration control file contents and facilitate locating items in the file. Originals shall not be released but dated copies will be available to anyone. At the end of the testing, all data records from the project file will be scanned into the BWID database. 


\subsubsection{Video Production}

A video will be taken of the RES demonstration at the cold test pit. The purpose of the video is to document the demonstrations as well as serve as a means of communicating information on the robotics tests to the media and public.

\subsubsection{Data Reporting}

To ensure that the demonstration results are reported to interested parties, the following two methods of data reporting will be used.

6.1.4.1 Technology Evaluation Report. The data generated by the demonstration as well as information on the planning and conductance of tests will be assembled and documented in a Technology Evaluation Report. The Technology Evaluation Report will summarize the tests, test results, lessons learned, and will provide recommendations for further development.

6.1.4.2 Publications. Information on the demonstrations and results will be submitted for publication to the Waste Management ' 94 Conference and other waste management or environmental restoration related journals, conferences, and meetings.

6.1.4.3 BWID Openhouse. A public openhouse will be held by BWID in July 1993 to display BWID projects, including the RES.

\subsection{Test Plan Changes}

Change requests to this plan may be initiated by any person participating in RES testing activities, but must be approved by the INEL BWRP PM, or qualified alternate. There will be two levels of changes as follows.

Level One changes are changes to the configuration of this plan that will nullify previously performed verification and validation efforts. Simply stated, such a change would raise uncertainty as to whether or not the same test results would be achieved if the test were repeated. Level One change requests must be clcarly documented. The documentation must specify the reasons for the change, the current condition, the proposed condition following the change, an explanation of the increased bencfits vs. the increased costs, and any secondary changes that will be necessary as a result of the primary change. Level One change requests will be reviewed and approved by the principal investigator and the RTDP coordinator (or alternate). The reviews and approvals will be clearly documented. Level One changes will require revalidation of the system for testing. Implementation of Level One changes and the revalidation of the system for testing will be under the direction of the INEL demonstration manager.

Level Two changes are those changes to the configuration of this plan that will not nullify the verification and validation achieved during testing. Simply stated, such a change would not raise uncertainty as to whether or not the same test results would be achieved if the test were repeated. Level Two changes shall be clearly documented by "red-lining" the procedures to match the procedure that is actually followed, initialling the procedure, recording the changes in the daily loghook, and photocopying the procedure to he sent to BWID. The change shall be reviewed and approved by the ORNL PM and the RTDP coordinator and implemented aceording to the appropriate operating procedures and test plan. Level Two changes will not require revalidation of the system hefore the continuation of testing. 
Test Plan documentation will be changed, as necessary, within one week following the testing at each facility to ensure that the current configuration is accurately documented at all times.

\subsection{Other Documents}

Copies of all test documentation from testing at each laboratory and equipment for the RES will be provided to BWID for the BWID database. Logbooks will be controlled per the procedures of the laboratory where the testing is performed, and photocopied for BWID records. 


\section{ANALYTICAL METHODS}

\subsection{Gravimetric Analysis of Filters}

All filters (HI-VOL, LO-VOL, and MSA cyclone) shall be dried by desiceation before weighing to ensure that there is no excess moisture in the filter. All filters shall be weighed on a five place electronic balance which has been calibrated and approved by the EG\&G Standards and Calibrations Lab (SCL). All filters shall be preweighed before transport to the eold test pit to establish a baseline weight. The filter will then he placed in a petri-dish and sealed until used at the sampling location. The sampler filter shall he handled using tweezers to minimize contamination of the filter from moisture or natural skin oils from the hand. The filter will be placed on the balance and the initial weight recorded in the project logbook.

After sampling the particulate filters shall be dried to remove any excess moisture trapped in the filter during sampling. The samples will then be taken to the weighing area and the filter placed on the balance. The weight will then be recorded in the project logbook. This procedure will be repeated for all filters. After all the filters have been weighed the samples will then be: transported for tracer analysis. The sampler filter shall be handled using tweezers to minimize contamination of the filter from moisture or natural skin oils from the hand. The filter will be placed on the balance and the initial weight recorded in the project logbook. 


\section{DATA REDUCTION, VALIDATION, AND VERIFICATION}

\subsection{Data Reduction}

Data reduction is not performed by the RES. The data collected by the system are displayed graphically on screens during testing.

\subsection{Data Validation/Verification/Recording}

The ORNL and INEL PMs will evaluate RES test data real-time using their experience and knowledge to verify that the test and acquired data are credible. Test results or data that are not credible will be considered a test failure and an enginecring evaluation will be made to decide if the test will be repeated, modified, or the test lailure simply documented and the next test started. Data will not be accepted if they were not taken in accordance with the established procedures or the procedure was not properly "redlined" in the ficld.

The data will be assembled, analyzed and documented in EG\&G Idaho, Inc., Informal reports. Validation of the data will be ensured by following this document. Qualification of the data will be conducted by the analysis team and will be approved by the analysis team leader. In addition, a peer review of the Technology Evaluation Report, where test results will be reported, will be performed.

- Measurement of mass of dust collected on filters

- Measurement of the amount of lutecium collected on filters

- Depth of increments of soil removed

- Ambient environmental conditions during testing (wind velocity, temperature, humidity).

During the test, depth measurements will he taken to determine the precision and accuracy with which increments of overburden soil can he removed from a subsurface disposal pit or trench. Calculations for determining precision and accuracy are as follows:

- Precision-The precision will be determined by calculating the mean for data gathered. Each 3 ft wide strip or "cut" performed by the excavator is deemed to be an independent replicate. Thus for each increment of soil removed in any phase of the test, at least five independent replicates exist.

- Accuracy-The accuracy will be decermined by calculating the standard deviation for the data gathered.

- Bias-The bias will be determined by calculating the difference between the expected value and the mean of the data. 


\section{QUALITY ASSURANCE}

\subsection{Data Quality Objectives (DQOs)}

Data quality ohjectives for the RES demonstration testing are listed below:

- Show with a $95 \%$ confidence level that cuts of 3,6 , and 12 in. of soil can be made with the RES to within \pm 1 in.

- Show that the spread of rare earth tracer (lutecium) caused by the soil-skimming activity will increase the level of tracer in the excavation area to at least 10 times background level

- Show with a 95\% confidence level that the retricval rate operating the RES remotely is $1.5 \pm 0.5$ drums per minute greater than the retricval rate operating the vehicle manually.

All other data gathered in the demonstrations will either be qualitative or, if quantitative, will be taken for information only. For these data, the objective is to obtain an accurate record of each test following the approved procedures. This information will be reported in the Technology Evaluation report, but will undergo no statistical analyses.

All testing (qualitative and quantitative) shall be performed in accordance with approved test procedures and with qualified personnel (as defined in the procedures). Any deviations will follow the requirements of Section 6.2 of this test plan.

A Professional Land Surveyor (PLS) will oversee the measurement of the soil depth-of-cut measurements. The PLS will approve the processes and procedures used to collect the data, and perform periodic inspections to ensure procedures are being followed.

Quality assurance of samples collected will be verified using several methods. All lilters used for sampling will be weighed on a balance having a current calibration certification from the SCL lab. Mass flow sensors or flowmeter will have current calibrations and calibration data from the SCL prior to use. The calibration information will he referenced in the project logbook and the reference data will be kept in the project file. Analytical results will be verified by the use of prepared standards, use of ciuplicate samples, and submission of blanks with each sample set. The standards, duplicates, and blanks will be submitted as a blind to the analytic laboratory.

The digestion method used for glass microfiber filters for lanthanide elements is fully described in the Analytical Chemistry ECL SOP IP1.3. The filters are digested on a hot plate using nitric acid and hydrogen peroxide. The method is a hot acid leaching procedure and not a total digestion. While the method does not result in total dissolution of the glass microfibers. previous studies have shown that rare earths are fully dissolved by this method. After digestion, the samples are analyzed by Inductively Coupled Plasma Mass Spectrometry. The determination of lanthanide elements by ICP MS is described in the Analytical Chemistry Unit ECL SOP IM6.1. The specific rare earth element "tracer" analyzed for will be luteciu.n.

The quality level for this work scope will he Quality Level B, as described in Science and Technology Department's Quality Program Plan-060) (S\&T QPP (66)) and the Waste Technology Development Department QPP-337. The analytical quality control will consist of the preliminary interference study to determine if other interlering elements or polyatomic species present problems during ICP-MS analysis for the two rare earth tracers. Included in each batch of samples (14-16 samples) will be a minimum of two blank filters from the same batch used for 
sampling, two air filters spiked with known quantities of rare earth tracers, and a reagent blank for a reagent impurity check. Instrument batch quality control samples will consist of an independent calibration standard check, and continuing calibration standard and blank checks every ten samples. A post-digestion spike will also be included in every instrument batch. These QC samples will provide precision and accuracy estimates for the analytical methodology.

Previously the lab has participated in analyses of rare earth tracers in support of the Cryogenic Retrieval Demonstration during the summer of 1992. The analytical methodology is described in existing laboratory SOPs for this work: the only change to the SOPs for this work scope is the identity of the tracer analysis. In 1992, this lab was approved by EG\&G Idaho, Inc. Environmental Restoration Department-Sample Management Office (ERD-SMO) for analytical support of the Cryogenic Retrieval Demonstration using these specific analyses.

Routine monitoring will he needed during the time that the samplers are operational in the field. During this check the person will ensure that each sampler is operational and running within operational limits of the flow. Any changes made to the sampler shall be noted in the field loghook, along with any other information such as temperature, humidity, weather conditions, etc. In addition, the person shall conduct a routine salety inspection of the equipment and general area to ensure that no unsafe conditions occur.

\subsection{Internal Quality Control Checks}

Internal quality control checks will be performed during and after testing. These include reviewing completeness and accuracy of the loghooks, executing performance and system audits (see Section 9.3), and checking to ensure that the established procedures are being followed.

\subsection{Performance and System Audits}

Performance audits are conducted (o) quantitatively evaluate the outputs of a measurements system. System audits are conducted to qualitatively evaluate the operational details of a quality assurance (QA) program. These audits will be conducted internally.

A performance audit will be conducted by the BWRP QA engineer at the time of the field demonstration at the INEL. This audit will involve the development of a checklist of critical operations and determining whether the operation was completed satisfactorily. Section 9.4 discusses corrective action.

A system audit to verily that the instrument(s) are operating within expected parameters will be done before and after the INEL demonstration by the respective operations personnel. This information will be documented in logbooks.

\subsection{Corrective Action}

If it is determined that the data being taken will not meet the test objectives because of an equipment malfunction or other reason, the criteria to continue the demonstration will be based on the following:

1. If the BWRP PMs can establish and implement a corrective action using the existing procedure and without compromising the test objectives, or drastically effecting either cost or schedule, then they may implement the corrective action. 
2. If the corrective action determined by the PM does compromise the test objectives, changes the existing procedures, or drastically affects cost or schedule, then the BWID Coordinator, BWRP PM, BWRP Condinator, and QA enginecr must approve of the plan prior to implementation.

Any compromise in test objectives that cannot be solved will be related to BWID and/or USID and documented in the Technology Evaluation Report. 


\section{EQUIPMENT AND INSTRUMENTS}

All instruments and equipment will be calibrated with approved calibration procedures. Prior to each test, the responsible test engineer will ensure all equipment requiring calibration is within their calibration dates. Specific delails (including range, accuracy, tolerance requirements, calibration procedures, a preventative maintenance schedule, and a list of critical spare parts) on all the test equipment and instrumentation is given in the individual test procedures found in Appendix A.

All equipment except the vehicle will be locked up at night and on days they will not be required. Protective measures will be taken to ensure that the equipment is not damaged during shipping to and from the INEL. 


\section{SUPPLIES, UTILITIES, AND FACILITIES}

This section addresses the supplies, utilities, and facilities that will be required to demonstrate the RES at the INEL only. Supplies, utilities, and facilities for testing at ORNL will be supplied by ORNL.

The INEL cold test pit can be accessed from only one road, shown on Figures 8 and 9. Utilities are not conveniently available at the pit, and a portable generator will supply electricity for the control systems and the data collection and transfer equipment. Fire extinguishers and the RWMC Emergency Response Team will also be available during the demonstration in case of fire or release of hazardous material (hydraulic fluid or oil spill). Fuel trucks will supply dicsel fucl for the RES vehicle. Spare parts for the RES will he supplied by ORNL.

A weather shicld structure will be used during demonstration of the RES excavation at the cold test pit. During an actual waste retrieval operation, an airtight building would be built over the site to minimize the spread of contamination. The weather shield will help simulate realistic retrieval conditions and provide an opportunity for more factual data to be collected on the amount of dust present during excavation.

A trailer for office space will be provided by BWID during the demonstration. BWID is supplying drinking water and lavatory facilitics at the ecold test pit.

Safety equipment is discussed in Section 12. The RES will arrive at the INEL on a llathed trailer and will remain at the cold test pit at night and during days when it will not be used. Security will be asked to check periodically on the equipment. 


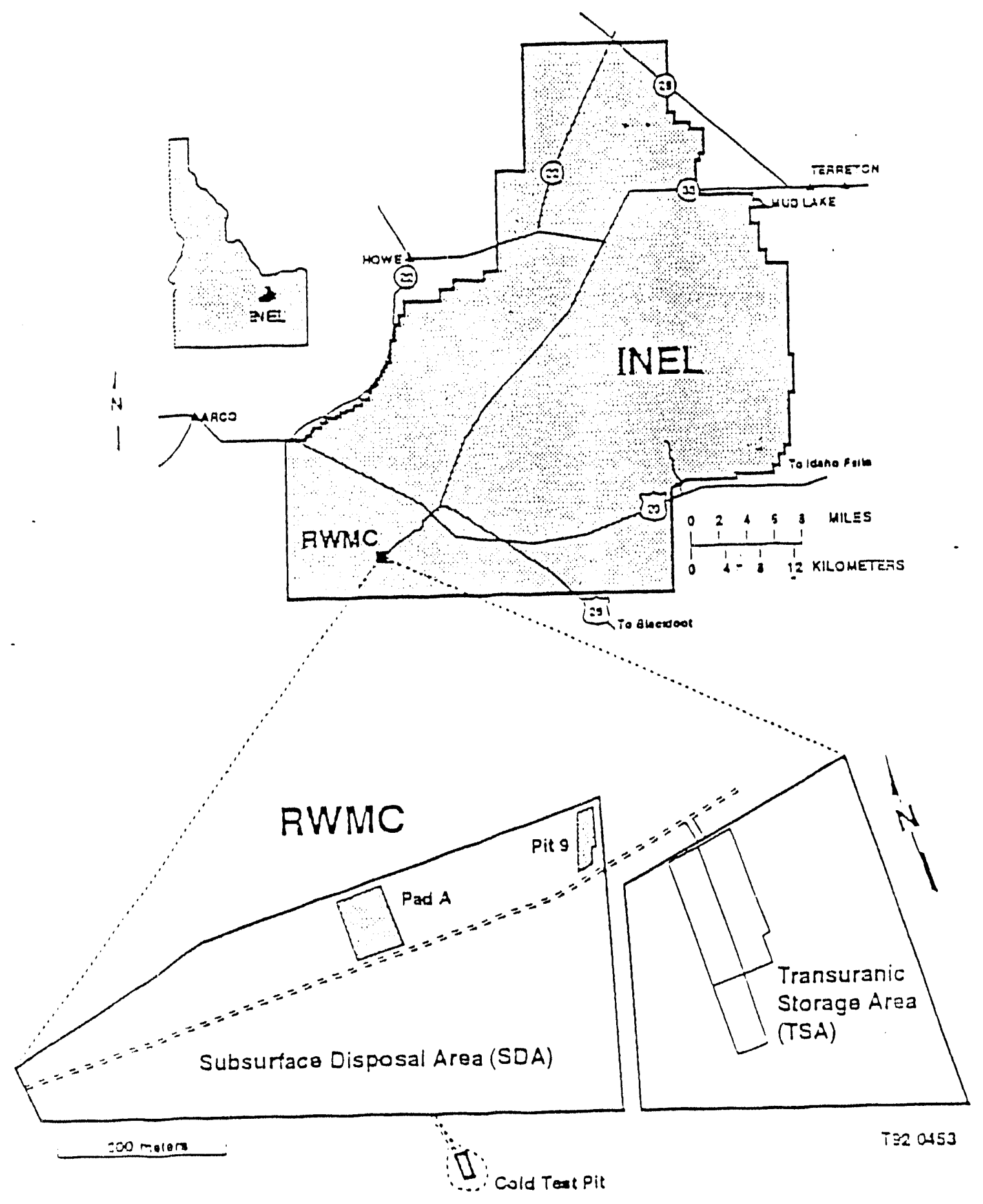

Figure 8. Location of cold test pit area. 


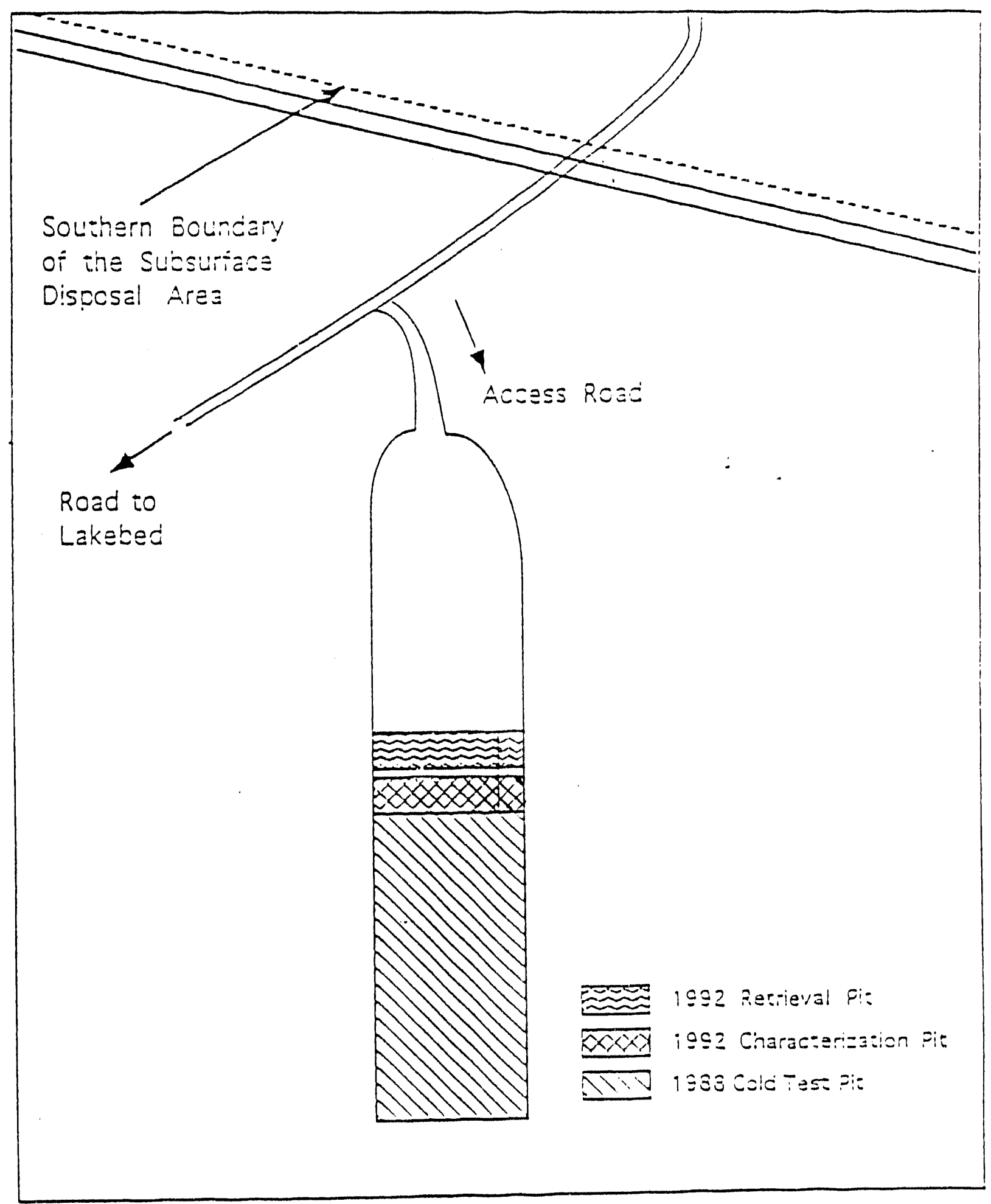

Figure 9. Access road to cold test pit area. 


\section{HEALTH AND SAFETY}

This section addresses the health and safety issues for the INEL demonstrations only. Health and safety for all other testing are the responsibilities of the personnel at the laboratories where the tests are performed. All work performed at the INEL must be reviewed and approved by the Facility Health and Safety Representative and documented in Safe Work Permits. All work will be performed in full compliance with all of the health and safety requirements for the BWID project as spelled out in the BWID PMP.

\subsection{Hazard Analysis}

The demonstrations at the INEL will be performed on clean, simulated waste. Safety is the highest priority for operations at DOE facilities and risks to workers must be removed to the greatest extent possible. Providing operators with the ability to control the equipment at a safe distance from the waste is the most reliable method of protecting them from the hazards of conventionai excavation.

Because safety is increased by developing remote technologies, and the demonstration will involve only very limited risk, regulatory and public acceptance of the RES demonstration is expected. The Hazard Classification determined for the RES demonstration is "routinely accepted by the public."

Using the vehicle inside a tent during testing requires that the exhaust be vented outside to protect personnel performing contamination control tests and filming the demonstration. As an additional safety precaution, personnel in the lest will wear $\mathrm{CO}, \mathrm{NO}_{\mathrm{x}}$, and $\mathrm{SO}_{\mathrm{x}}$ film badges.

\subsection{Employee Training}

Any specialized training for equipment used in the various tests will be specified in the detailed test procedures. A training session will be provided onsite for the INEL backhoe operator who will operate the RES during manual excavation performed in a bubble suit.

All personnel involved in the demonstrations (other than short-term visitors who must be escorted by a qualified person at all times) must have up-to-date INEL blue card training prior to access $t o$ the cold test pit area. This training will be provided by INEL personnel. Access to the RWMC should not be necessary, but if RWMC lacilities must be used for an unexpected activity, RWMC access training will be available at the gate during working hours. This training will be required for unescorted access.

\subsection{Protective Equipment}

Specific protective equipment will be as specified in the test procedures and in the Safe Work Permits. The INEL will provide the following. where needed:

- Hard hats

- $\quad$ Safety glasses

- Dust masks 
- $\quad$ Lifting belts

- Protective shoc covers (to replace safety shoes)

- $\mathrm{CO}, \mathrm{NOx}$, and SOx badges.

The RWMC Safety Engineer shall conduct a safety walkdown of the test area bi-weekly. Safety discrepancies and concerns shall be reported to the BWID Integrated Demonstration Coordinator. The BWRP will act to correct any safety concerns that arise in a timely manner when requested to do so by the BWID Integrated Demonstration Coordinator or designee.

\subsection{Emergency Response Plan}

A BWID representative shall check in with the RWMC Shift Manager, or Roving Watch, at the beginning and end of each work shift. At the start of a shift, the BWID representative shall provide the RWMC Shift Manager, or Roving Watch, with a list of personnel at the cold test pit. This list will facilitate accounting for personnel in the event of an emergency. The BWRP Demonstration Manager will provide a list to the BWID representative of personnel supporting the BWRP portion of the demonstrations.

The RWMC Shift Manager shall generate and transmit any necessary reports for abnormal or emergency situation with BWID assistance. The BWRP will support the BWID in whatever manner necessary should an occurrence result.

To prepare for an emergency, the RWMC Shift Manager shall generate a long-term shift order, in accordance with Environmental Restoration and Waste Management Department Procedure 16.2, Shift Orders. The shift order will identify hazards associated with all BWID activities at the cold test pit. The BWRP will supply any requested information to aid in completing the shift order.

If an individual at the cold test pit determines at any time that an abnormal event or emergency is occurring, that individual shall notify the onsite BWID representative of the situation immediately. During normal RWMC working hours, the onsite BWID representative shall notify the RWMC Shift Manager, by 6-Net radio, or by telephone (526-2767) of any abnormal or emergency situation. Initial response $t o$ an emergency at the test area will be made by the RWMC Emergency Brigade. Subsequent activity will be in accordance with the RWMC Emergency Plan/RCRA Contingency Plan and at the direction of the RWMC Emergency Action Director.

During RWMC nonworking hours, the onsite BWID representative shall be responsible for initiating emergency response by contacting the RWMC Gate, Post 301, (526-2259) or the RWMC Roving Watch (by radio) as identificd in the RWMC Emergency Plan/RCRA Contingency Plan Section 7.8 EIP 25, Backshilt Contingency Plan/Duty Officer Program.

Table 2 shows a list of RWMC and BWID contacts.

\subsection{Spill Control}

The RWMC Emergency Response Team will be supporting the cold test pit demonstrations. In the event of a spill (involving hydraulic lluid, engine oil, etc.), the RWMC Spill Prevention 
Table 2. RWMC and BWID emergency contacts.

\section{RWMC}

Cline, Skip

$526-2767$

RWMC Shift Manager

$526-2766$

Bishoff, Jim

RWMC Operations Manager

$526-6280$

French, Doug

RWMC Facility Manager

BWID

Kostelnik, Kevin

$526-9642$

Buried Waste Integrated Demonstration Coordinator

526-5206 (beeper)

Heard, Bob

526-7379

BWID Representative

$526-5242$ (beeper)

Bonnenburg. Rudy

$526-2546$

BWID Representative and Deployment Manager

526-6679 (beeper)

Watson, Larry

$526-2232$

BWID Representative and Deployment Manager

526-5455 (beeper)

Control and Countermeasures (SPCC) procedures will be followed. After the spill is controlled, BWRP will be responsible for proper disposal of the matcrial. Spills on the ground $<3$ gallons do not require reporting as an unusual occurrence.

Any maintenance required on the excavator will he performed with the vehicle parked on a plastic tarp. Small herms will he formed on cach side of the tarp to prevent leakage of any fluids onto the soil.

Material Safety Data Sheets (MSDSs) for each chemical used during the demonstrations (hydraulic lluid, fucl, etc.) will be onsite and available during the demonstration in the trailer office. 


\section{RESIDUALS MANAGEMENT}

This section addresses residuals management at the INEL only. Residuals from tests at other laboratories will be managed in accordance with the regulations of the facility in which they are performed.

For the INEL demonstration, the only anticipated residuals are the overburden from the cold test pit and the simulated waste retrieved from the pit. The overburden is clean soil spiked with small amounts of a rare earth tracer and will he returned to the pit when the RES tests are completed. The simulated waste will be disposed of properly in a landfill. If a container is breached during excavation, any soil littered with simulated waste will also be disposed of in a landfill.

In the event of a leak in the RES hydraulic, oil, or fuel system, any contaminated soil or other material will be disposed of in accordance with regulations for hazardous waste disposal.

Management of materials used during the demonstration of the RCS, which will be performed in conjunction with the RES, are addressed in the RCS test plan (EGG-WTD-107(1)4). 


\section{REGULATORY REQUIREMENTS}

This section addresses regulatory requirements for the RES demonstrations at the INEL. The regulatory requirements for testing at the other national laboratories will be similar to those at the INEL and are the responsibility of the BWRP personnel at their facilities. Because the INEL demonstrations will be performed at a simulated waste pit, and not on actual waste, the only regulatory requirement is to comply with the National Environmental Policy Act (NEPA).

\subsection{National Environmental Policy Act}

The environmental impact from this demonstration will be minimal. Removing the overburden and simulated waste will result only in short-term noise and dust. The excavations planned will be similar to those performed during small construction activities. The simulated waste in the test pit is nonhazardous and will not have a significant impact on the environment. After the demonstration is completed, the clean soil will he returned to the pit and the simulated waste will be disposed in a landfill.

An Environmental Checklist (EC) was completed for these activities. Subsequently, a Categorical Exclusion (CX) was prepared for these demonstrations and A. A. Pitrolo, Manager, DOE-ID, approved the CX on July 21, 1992.

\subsection{Occupational Safety and Health Administration (OSHA)}

The RES is a remote system, and activities will not be performed in a hazardous environment, therefore OSHA regulations do not apply. Protective gear will be supplied as necessary, and SWPs will cover activities during the demonstration. Shoring the sides of the excavated area will not be necessary because no one will be allowed to enter the excavated area. In case of an unplanned oceurrence requiring personnel to enter the pit, the sides of the pit will be shored. 


\section{REFERENCES}

1. Letter from K. M. Kostclnik, EG\&G Idaho Inc., to Buried Waste Integrated Demonstration Program distribution, "BWID Demonstration Test Objectives," KMK-39-93, April 1993, (available from Kostelnik filc).

2. O. D. Duncan and M. Stenbeck, "Are Likert Scales Unidimensional?," Social Science Research, 16, 1987, pp. 245-259.

3. G. E. Cooper and R. P. Harper, The Use of Pilot Rating in the Evaluation of Aircraft Handling Qualities, Moffett Field, CA, National Acronautic and Space Administration, Ames Research Center, NASA Report TN-D-5153. April 1969.

4. G. B. Reid, C. A. Shingledecker, and F. T. Eggemeier, "Application of Conjoint Measurement to Workload Scale Development," Proceedings of the Human Factors Society 25th Annual Meeting, 1981.

5. S. G. Hart and L. E. Staveland, "Development of NASA-TLX (Task Load Index): Results of Empirical and Theoretical Research," Human Mental Workload, edited by Hancock and Meshkati, Elscvier Science Publishers B.V., 1988, pp. 139-183.

6. M. S. Sanders and E. J. McCormick, Human Foctors in Engineering and Design, McGraw-Hill Book Company, 1987, pp. 51-53.

7. W. W. Wierwille et al., "On the measurement of pilot workload: A comparison of assessment techniques addressing sensitivity and intrusion issues," Engonomics, 27 (10), 1984.

8. S. Walker, R. A. Hyde, Remote Characterization System Test Plan, EGG-WTD-10704, May 1993.

9. M. R. Winberg. Specifications of the Addition of a Charactcrization and a Retrieval Cell to the Cold Test Pit (As-Built), Engineering Design Filc, EG\&G Idaho, Inc., December 1992. 


\section{BIBLIOGRAPHY}

Freightliner Corporation, Freightliner SEE Tractor, Small Emplacement Excavator, Company Brochure, Porlland, OR, 1987.

D. Varacalle, Environmental Evaluation Study of INEL-Owned Heavy Equipment for TRU Waste Exhumation, EE-87-004, May 1987.

B. L. Burks, S. M. Killough, D. H. Thompson, "Development of a Telcoperated Backhoe for Buricd Wastc Excavation," Nuclear and Hazardous Waste Management, Spectrum '92

International Topical Meeting, Boise, Idaho, August 23-27, 1993, pp. 93-97. 


\section{Appendix A}

\section{Engineering Test Sequences}


A-2

$$
\text { A-2 }
$$




\section{Appendix A}

\section{Engineering Test Sequences}

\section{A-1. HUMAN FACTORS ANALYSIS OF THE CONTROL SYSTEM}

\section{A-1.1 References}

Human Factors Standards for the following:

- $\quad$ Lighting

- $\quad$ Noise levels

- Anthropometric

- Displays

- Controls

- Operator loading

- Atmospheric conditions.

\section{A-1.2 General}

The purpose of this test sequence is to assess the usability of the control system by performing a human factors study. For any system to be useful, it must be easily operated. In the environment of waste remediation, a useful system must also leave no room for critical error.

This study can be divided into three objectives. The first objective is to assess the usability of the control station. This includes evaluating operator control over crane speed, operator control over position of crane, ease of operation, quality of viewing screens, performance of control devices, and usefulness of graphics. The second objective is to identify factors that may affect performance. The third objective is to identify any deficiencies.

The step-by-step procedures are given later in this test sequence. Data will be determined valid by the test administrator. If the procedures are deviated from, the test administrator will redline this procedure to reflect those changes.

\section{A-1.3 Materials and Equipment}

The following materials and equipment will be required to perform the tests outlined above and described in detail below.

- 1 lab notebook

- 2 pens

- Watch (resolution of one second) 
- $\quad$ Tape measurer $(25 \mathrm{ft})$

- 5 subjects for operators

- Remote Excavation System

- High-Level Control Station.

\section{A-1.4 Specific Precautions}

No personnel should be in the immediate area of the excavator while subjects are operating the equipment for this test.

\section{A-1.5 Prerequisites}

None.

\section{A-1.6 Procedure}

Following are the step-by-step procedures for performing a human factors analysis of the high-level control system for the Remote Excavation System. Any time that one of the steps refers to recording some data, it will be recorded in a logbook. Only one subject will be tested at a time. Perceptions of the subjects will be solicited by using the global-guided scale shown in Figure A-1.

Step 1. Assess the usability of the control station.

Step 1.1 Explain the control system and how it can be used to control the excavator. This training session should last approximately 10 minutes. Each subject will receive the exact same training. The contents of the training will be kept in the project file.

Step 1.2 Operator control over vehicle speed. The subjects will be asked to drive the excavator in a precise, predetermined manner. The following data shall be recorded: (1) operator's thoughts on the controls and displays relating to speed control and feedback, (2) perceived level of control, and (3) perceived difficulty. The operators will be asked to verbalize their thoughts while operating the excavator. These thoughts will be recorded in a logbook. The global-guided scale shown in Figure A-1 will be used to measure the operator's perceived level of control and perceived difficulty.

Step 1.3 Operator control over vehicle position. The subject will be asked to move the excavator in a precise way. The following information will be recorded: (1) time it takes the subject to perform this task, (2) number of errors, (3) operator's thoughts on the controls and displays, (4) perceived level of control, (5) perceived difficulty, and (6) accuracy of movements. Time will be measured using a stop watch and will be recorded to the nearest second. The number of errors will be determined subjectively by counting the number of times the operator must perform a corrective action. An example of this would be for the operator to have the vehicle move in the opposite direction than 
- THE SYSTEMS CAPABILITIES WERE MORE THAN ADEQUATE IN ASSISTING THE OPERATOR TO ACHIEVE OPTIMUM TASK SUCCESS.

I WOULD NOT RECCOMEND ANY CHANGES OR IMPROVEMENTS.

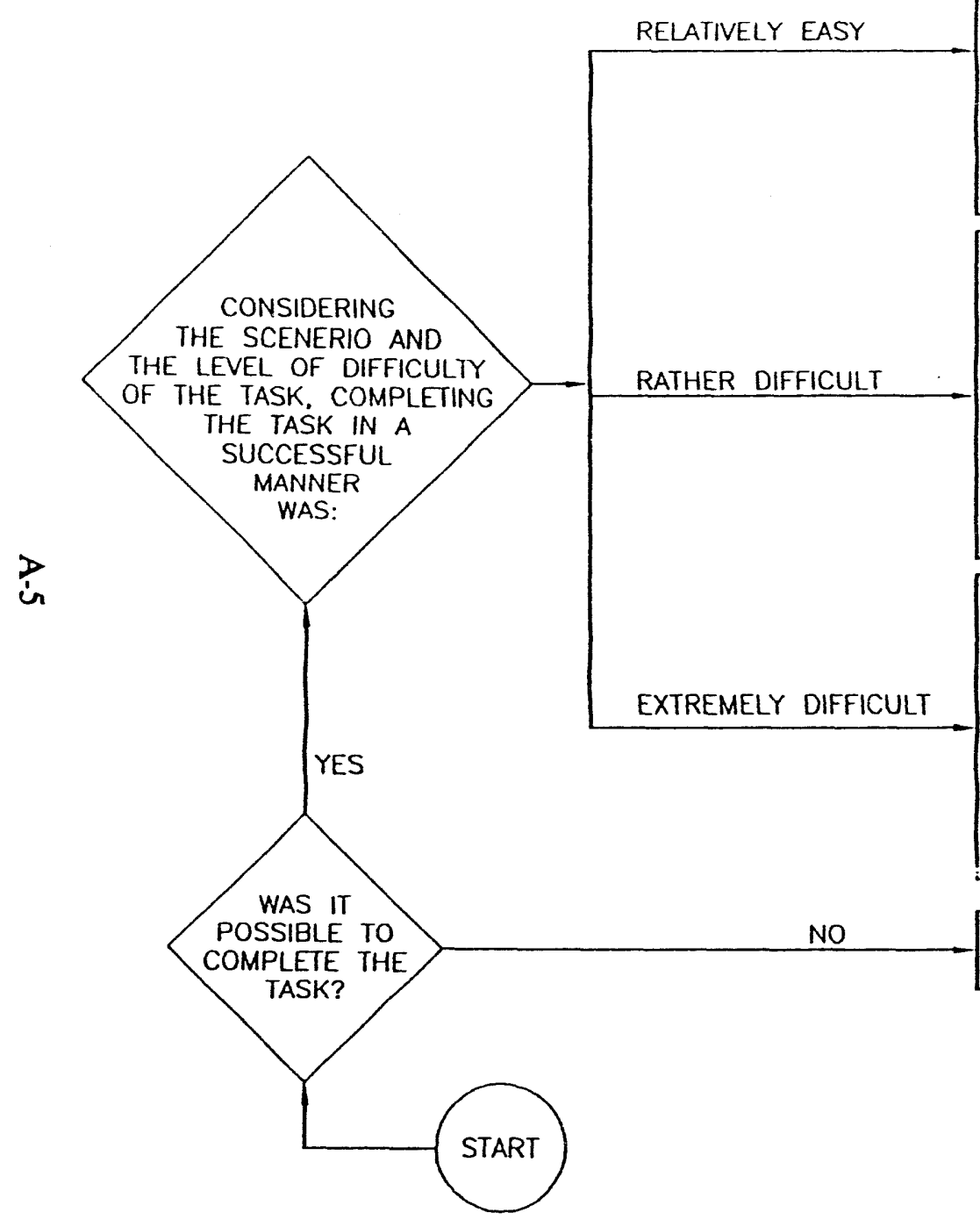

- TASK PERFORMANCE WAS NOT SERTOUSLY AFFECTED BY ANY SYSTEM CHARACTERISTICS THERE COULD BE SOME MINOR IMPROVEMENTS. CLEARLY ADEQUATE.

- THERE WERE SOME PROBLEMS. COULD BE USED AS DESIGNED, BUT WOULD BE BETTER WITH IMPROVEMENTS. PROBABLY ADEQUATE.

WORK LOAD WAS HIGH ENOUGH TO DEFINETLY REQUEST CHANGES. AN OPERATOR WITH LESS EXPERIENCE WOULD HAVE DIFFICULT IN COMPLETING THE TASK. SATISFACTORY ONLY AS A BACK-UP.

- IMPROVEMENTS ARE NEEDED. PERFORMANCES OF AVERAGe OPERATORS WOULD BE MARGINAL. I HAD DIFFICULTY AND WOULD INSIST ON IMPROVEMENTS.

- MAJOR IMPROVEMENTS ARE NEEDED. AVERAGE OPERATORS WOULD NOT BE ABLE TO COMPLETE THE TASK. EXCESSIVE WORK. MARGINAL AS A BACK-UP SYSTEM.

MAJOR DEFICIENCIES WHICH REQUIRE MANDATORY IMPROVEMENTS INADEQUATE FOR SUCCESSFUL TASK COMPLETION WITHOUT EXTREMELY HIGH LEVELS OF WORK LOAD. NOT ACCEPTABLE.

- WORK LOADS TOO HIGH FOR AVERAGE OPERATOR TO COMPLETE THE TASK. SYSTEM IS UNSATISFACTORY.

- WORK LOADS ARE SO HIGH AS TO NOT ALLOW TASK COMPLETION EXCEPT FOR THE MOST SKILLED OPERATORS. DOUBTFUL THAT THE SYSTEM CAN BE USED EXCEPT FOR THE SIMPLEST CONDITIONS.

I COULD NOT COMPLETE THIS PARTICULAR TASK GIVEN THE EXISTING SYSTEM.

Figure A-1. Global-guided scale. 
intended. The operators will be asked to verbalize their thoughts while operating the excavator. These thoughts will be recorded in a logbook. The global-guided scale shown in Figure A-1 will be used to measure the operator's perceived level of control and perceived difficulty. The accuracy is a separate test OR should we measure to the nearest $1 / 2 \mathrm{ft}$ from the predetermined course at five distinct locations.

Step 1.4 Ease of operation. The operators will be asked to perform the following: (1) drive the excavator forward; (2) drive the excavator in reverse; (3) excavate a small object from the ground. The following will be recorded: (1) operator's thoughts on the controls and displays, (2) perceived level of control, and (3) perceived difficulty. The operators will be asked to verbalize their thoughts while operating the excavator. These thoughts will be recorded in a logbook. The globalguided scale shown in Figure A-1 will be used to measure the operator's perceived level of control and perceived difficulty.

Step 1.5 Quality of viewing screens. The operators will be asked their opinion on the quality and adequacy of the viewing screens. The global-guided scale shown in Figure A-1 will be used to extract a rating for the quality of the viewing screens and the adequacy of the viewing screens. Any suggestions will be recorded.

Step 1.6 Performance of control devices. The operators will be asked their opinion on the performance of the controls. The global-guided scale shown in Figure A-1 will be used to extract a rating for the performance of control devices. Any suggestions will be recorded.

Step 2 Determine the adequacy of operator control over camera positions and adequacy of views

Step 2.1 With the vehicle stationary, the operator will be asked to move the cameras to look at objects at $0,90,180$, and 270 degrees from straight ahead.

Step 2.2 The human factors engineer will solicit the operator's opinion on the adequacy of their control over the camera positions and adequacy of the views allowed by the camera system by using Figure $A-1$.

Step 3 Identify factors that may affect performance.

Step 3.1 The human factors engineer will record information in a logbook based on her judgement and results of the previous tests. Information to be considered includes: lighting, anthropometrics, noise, workload, alarms, environment, controls, displays, feedback, physical space and layout, and cameras.

Step 4 Identify any deficiencies.

Step 4.1 As a result of the previous tests, the human factors engineer shall record any system control deficiencies that affect the usability of the system. In addition, the safeguards against losing control, communication, or data will be recorded. 


\section{A-2. OVERBURDEN REMOVAL TESTS}

\section{A-2.1 References}

None.

\section{A-2.2 General}

\section{Overview}

The purpose of this test sequence is to outline the methods that will be used to evaluate soil overburden removal using the Remote Excavation System (RES). RES overburden removal will be demonstrated at the cold test pit during FY-93. The purpose of these tests is to evaluate the Remote Excavation System for the removal of orerburden soils at the Subsurface Disposal Area (SDA) located at the Radioactive Waste Management Complex (RWMC) at the Idaho National Engineering Laboratory (INEL).

The step-by-step procedures are given later in this test sequence. Data will be determined valid by the test administrator. If the procedures are deviated from, the test administrator will red line this procedure to reflect those changes.

The overall test sequence involves multiple activities and measurements. Basically, the RES will be used (both backhoe and front loader) to remove a designated amount of soil. During the removal, samples will be taken to measure the generation and spread of contamination by taking air particulate samples. The samples taken will measure the amount of lutecium (a rare earth tracer that will be spiked into the overburden) that was released. This will allow comparison of equipment and techniques to the amount of contamination spread. Also, at each designated amount of soil removal, the precision and accuracy of the cut will be measured. At two specific times (1' $9^{\prime \prime}$ and 3'9" from the surface), the Remote Characterization System will be used to survey the waste area. Overburden will be removed $3^{\prime \prime}, 9^{\prime \prime}, 1^{\prime} 9^{\prime \prime}, 2^{\prime} 9^{\prime \prime}, 3^{\prime} 9^{\prime \prime}, 4^{\prime} 3^{\prime \prime}, 4^{\prime} 6^{\prime \prime}$, and $4^{\prime} 9^{\prime \prime}$ from ground level.

\section{Operation of RES}

The RES shall be set up and prepared for operation as per the initialization steps in the excavator Operators Manual. The excavator shall be remotely positioned in the proper location for the particular overburden removal evolution.

\section{Contamination Spread Measurements}

During removal operations samplers will be located at strategic locations to collect air particulate samples to be analyzed for rare earth tracers. No contamination control measures will be employed (e.g., use of water or other soil fixatives to minimize dust generation).

The cold test pit overburden will be spiked with a rare earth tracer (Lutecium) to provide an easy method to analyze and evaluate samples. The samples will be analyzed to determine the effectiveness of equipment and techniques used to remove overburden soils and the ability to minimize the generation and resuspension of fugitive dusts during soil overburden removal operations. Each test will have a known amount of rare earth tracer placed at strategic locations within the overburden. The tracer will be placed into the ground in bore holes drilled in a grid 
pattern at a depth of $5 \mathrm{ft}$. Figure A-2 shows where the lutecium bore holes will be drilled in the pit.

The bore holes will be filled completel; with a mixture of predried, screened soil and tracer. The soil will be predried to $<4 \%$ moisture by weight and screened using a mesh sieve to remove any large soil particles. The soil will then be mixed with the tracer at a level of 10 times greater than the background level of that tracer. The tracer to be used is lutecium. The tracer is commercially available in the form of oxide powders and characterized for particle size.

The primary analytical method will be to collect air particulate samples at strategic locations around the test area. Air particulate samples around the perimeter will be collected using high volume 4 in. samplers (10-20 cfm flow rate) and low volume $47 \mathrm{~mm}$ samplers (2-5 cfm flow rate). These samplers will be located at strategic locations upwind and downwind of the immediate test area to determine the degree to which any tracers will migrate. The exact location of the samplers will be noted in the field notebook. However, Figure A-3 shows the approximate layout to be used.

Samples will be analyzed for rare earth tracers using the Inductively Coupled Plasma-Mass Spectrometry (ICP-MS) method by the EG\&G Environmental Chemistry Unit (ECU).

Samples and data will be analyzed using methods used in previous tracer sampling studies conducted at the cold test pit.

\section{Overburden Cut Precision and Accuracy Measurements}

The purpose of this test is to assess the precision and accuracy of the RES for overburden removal. This includes testing the front loader and backhoe cuts. Measurements will be taken by

\section{Characterization Side}

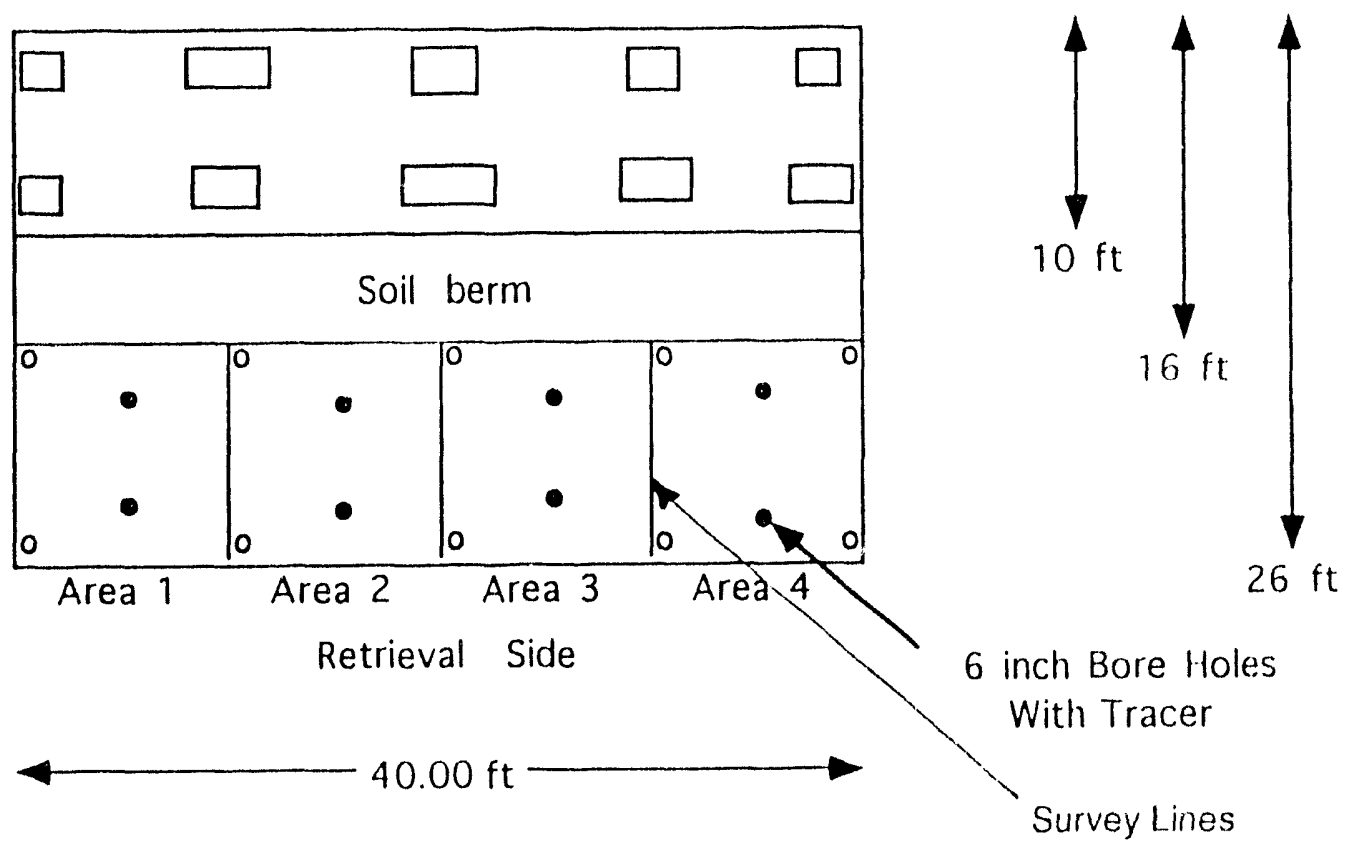

Figure A-2. Retrieval cells of the cold test pit. Bore holes for rare earth tracers and survey lines are shown. 


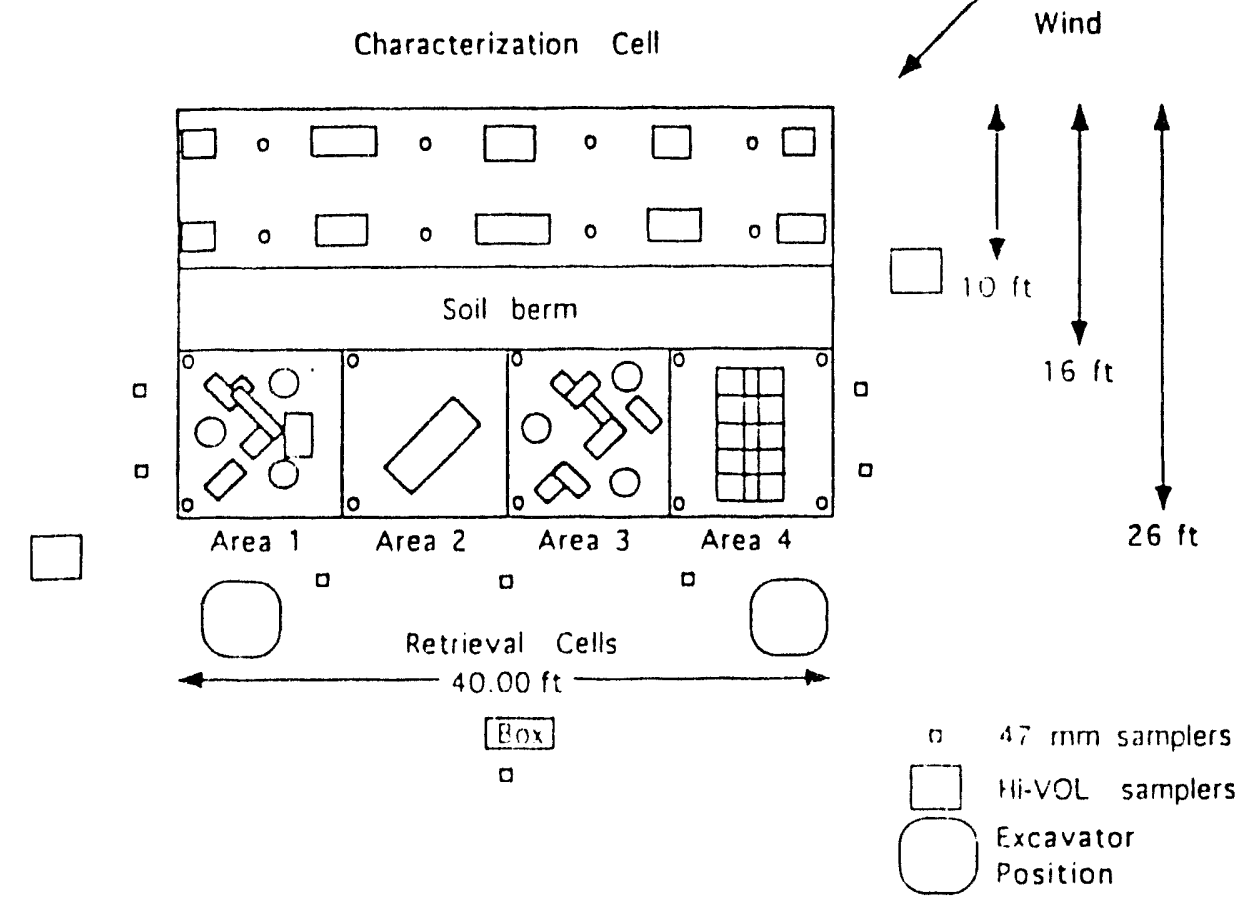

Figure A-3. Approximate layout of samplers at the cold test pit.

a surveyor at the breaks as well as every $2 \mathrm{ft}$ along a line between each of the inserted tubes (Figure A-2). By doing this, 30 measurements plus break measurements will be recorded for each cut. Measurements will be recorded during the surveys (see Table A-1).

\section{Operation of the RCS}

The RCS will survey between layers of soil overhurden at the locations 1'9" and 3'9" below grade.

\section{A-2.3 Materials and Equipment}

Following is a list of materials and equipment that will be required to perform the tests outlined above and described in detail below. These include: operation of the RES, contamination spread measurements, overburden cut precision and accuracy measurements, and operation of the RCS.

\section{Operation of RES}

1. Remote Excavation System

2. Control Van and associated equipment

3. Stopwatch (resolution of 1 second). 
Table A-1. Topographical Survey Data Shect.

DATE TESTPHASE TIME

(AM/PM)

NAME OF PERSON TAKING MEASUREMENTS

NAME OF PERSON RECORDING DATA INITIALS

SPECIAL CONDITIONS/NOTES

\begin{tabular}{|r|r|r|r|r|r|r|r|}
\hline & & & & & & & \\
\hline A1 & A2 & A3 & A4 & A5 & & & \\
\hline B1 & B2 & B3 & B4 & B5 & & & \\
\hline C1 & C2 & C3 & C4 & C5 & & & \\
\hline$D 1$ & D2 & D3 & D4 & D5 & & & \\
\hline E1 & E2 & E3 & E4 & E5 & & & \\
\hline & & & & & & & \\
\hline
\end{tabular}

NORTHEAST

- Place data for each depth reading in the blocks above.

- Record data starting in block A1 and ensure orientation of data collection malches orientation of pit. (See Figure 5 of the Test Plan)

- There are extra blocks provided for use if needed (i.e., not all will be filled in). 


\section{Contamination Spread Measurements}

1. 4 ea. Anderson HI-VOL Samplers

2. Sartorius 5-place analytical balance

3. 4 in. glass fiber particulate filters

4. 4-8 $47 \mathrm{~mm}$ lo-vol particulate samplers

5. Instrument shelter and portable generator.

HI-VOL particulate air samplers contain a 4 in. air particulate filter that is held in the sampler by a screw in the retaining ring. The sampler unit is self contained with the pump, filter, and flow monitor. Air flow through the sampler is set to run at $10-20 \mathrm{cfm}$.

The $47 \mathrm{~mm}$ samplers consist of a sampler base, filter holder, and retaining ring. The retaining ring holds the $47 \mathrm{~mm}$ particulate filter in place in the filter holder. The filter holder is then screwed in place to the sampler base at the sample location. All of the $47 \mathrm{~mm}$ samples will be connected to rotary vane vacuum pumps located at the instrument shelter. The flow is regulated through each sampler by valves located in the instrument shelter. The flow through each sampler is measured using electronic mass flow sensors. The outputs from each sensor are connected to a datalogger and portable computer for data storage. Power for the instrument shelter is supplied by a portable generator.

\section{Overburden Cut Precision and Accuracy Measurements}

1. Survey Level Instrument

2. Instrument Legs

3. Survey Level ROD

4. Survey Tape

5. Survey Field Notebook

6. Controls van and accompanying equipment

7. Remote Excavation System.

And for vertical control, the following will be used:

8. NGS Brass Cap Z430

9. Elevation $5010.27 \mathrm{ft}$. 


\title{
Operation of the RCS
}

\author{
1. Remote Characterization System \\ 2. Control Van and associated equipment (same as RES) \\ 3. Stopwatch (same as RES).
}

\section{A-2.4 Specific Precautions}

\section{Environmental Conditions}

During the overburden removal tests, the wind direction, wind velocity, temperature, humidity, and barometric pressure will be recorded. However, under specific conditions, the data may no longer be useful. For example, if the wind direction changes past a certain range, the monitors will not be sampling at the appropriate locations. Likewise, if the wind velocity exceeds a certain amount, the amount of dust measured will not represent what the equipment is generating. If the humidity rises, it can act as a contamination control method. However, this type of data would be very useful to the Uranium Soils Integrated Demonstration (USID) Program.

Therefore, the following criteria have been set to ensure testing will be terminated if the environmental conditions exceed these values. The National Oceanic \& Atmospheric Administration (NOAA) continuously monitors environmental conditions at multiple locations across the INEL, including at the RWMC. NOAA has agreed to contact our program should any of the criteria be exceeded.

1. Should the wind direction not be within the wind rose range as identified in Figure A-4, the tests should be terminated until the wind changes back into tolerance.

2. Should the wind speed exceed $15 \mathrm{mph}$, then the tests will be terminated until the wind has subsided to under $15 \mathrm{mph}$.

The average daily temperature at the Central Facilities Area (CFA) in June is $33^{\circ} \mathrm{F}$, with a maximum daily air temperature range of $55^{\circ} \mathrm{F}$. The highest daily maximum temperature recorded at CFA in June was $100^{\circ} \mathrm{F}$ and the lowest daily minimum was $23^{\circ} \mathrm{F}$. The highest daily average in June was $83^{\circ} \mathrm{F}$ and the lowest daily average was $40^{\circ} \mathrm{F}$. The average number of freeze/thaw cycles in June at the CFA was 6, with a maximum number of 17 , and a minimum of 0 .

The average sunrise time at CFA in June is approximately 4:51 and sunset is 8:14 Mountain Standard Time.

The average total precipitation in June at CFA is 1.18 in., with a maximum of 3.89 in. and a minimum of 0.02 in. The average number of days (\%) on which precipitation was recorded at CFA in June is: $34 \%$ (trace or more), $23 \%$ (0.01 in. or more), $11 \%$ (0.10 in. or more), $1.9 \%$ ( 0.50 in. or more), and $0.3 \%$ (1.0 in. or more). In June at CFA, $77.5 \%$ of the time the ground surface is dry; $14.4 \%$ of the time the ground surface is moist (e.g., dew); and $8.1 \%$ of the time the ground surface is wet (standing water in small or large pools at the surface). 

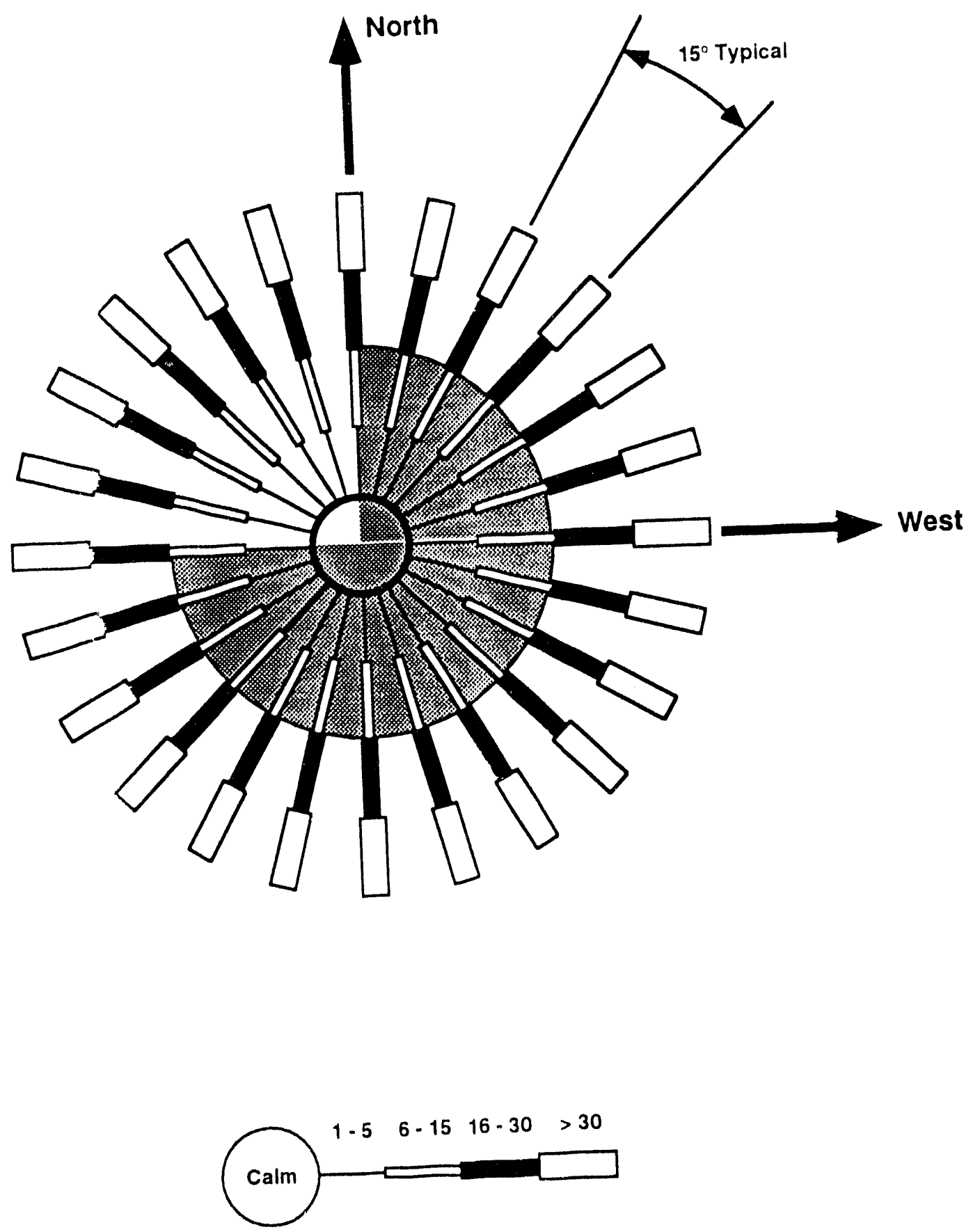

Figure A-4. The shaded zone in the above wind rose indicates the go zone for performing contamination analysis dust collection. The allowable wind speed is $15 \mathrm{mph}$ and the allowable wind direction is from the west, southwest, southeast, and east as indicated. 
The average relative humidity in June at CFA is $36 \%$. The average maximum relative humidity is $73 \%$ and minimum is $16 \%$. The absolute maximum relative humidity is $100 \%$ and minimum is $6 \%$.

The average atmospheric pressure in June at CFA is 25.02 in. $\mathrm{H}$. The average maximum atmospheric pressure is $25.09 \mathrm{in}$. $\mathrm{H}$ and minimum is $24.96 \mathrm{in}$. $\mathrm{H}$. The absolute maximum atmospheric pressure is 25.39 in. $\mathrm{H}$ and minimum is 24.55 in. $\mathrm{H}$.

The above average temperatures, sunrise and sunset times, total precipitation, and atmospheric pressures were given for information only. The actual conditions will be recorded in logbooks, but the only operating parameters will be wind speed and direction.

\section{Analysis}

It should be noted that rare earth tracers are lighter than Uranium and Plutonium and that only broad generalizations can be made regarding contamination spread because of this fact. For a given particle size; however, the Uranium will not migrate as much as a rare earth tracer given the same environmental conditions. The data taken in this test procedure then, will provide a method to infer generalizations about contamination spread in a given environment.

\section{A-2.5 Prerequisites}

\section{Operation of RES}

The RES must be in working order.

\section{Contamination Spread Measurements}

The overburden on the retrieval cell needs to be spiked with Lutecium. This action is currently planned for May 1993.

\section{Overburden Cut Precision and Accuracy Measurements}

The following preliminary actions will be taken prior to performing the survey.

A. Record Information in Field Notebook

- Date

- Personnel

- Level instrument brand, model, and calibration date

- Vertical control

- Weather conditions. 


\section{B. Examine Pit and Determine Location of Foresights}

- Use 5-ft cross-section interval, unless field conditions indicate otherwise. The interval will be recorded in the field notebook.

\section{Operation of RCS}

The RCS needs to be in working order and all instrumentation calibrated.

\section{A-2.6 Procedure}

There are six basic steps to this test sequence. A flowchart is provided (Figure 3) to show how some of the steps are performed in parallel while others are serial. Following is the detailed test procedure for all overburden removal activities.

Step 1. Use RES to remove a section of overburden. Overburden will be removed incrementally at $3^{\prime \prime}, 9^{\prime \prime}, 1^{\prime} 9^{\prime \prime}, 2^{\prime} 9^{\prime \prime}, 3^{\prime} 9^{\prime \prime}, 4^{\prime} 3^{\prime \prime}, 4^{\prime} 6^{\prime \prime}$, and 4'9" from ground level. Step 2.4 is performed in parallel with step 1 .

Step 1.1 Remove layers of overburden with the front end loader, if possible. If the front end loader will not remove the overburden, use the backhoe.

Step 2. Measure the contamination spread because of the RES. This same procedure will be used regardless if the RES backhoe or front loader is being used.

Step 2.1 Methods used to weigh and handle particulate air filters

All filters ( 4 in. and $47 \mathrm{~mm}$ lo-vol) will be dried by desiccation before weighing to ensure that there is no excess moisture in the filter. All filters will be weighed on a 5 place electronic balance that has been calibrated and approved by the EG\&G Standards and Calibrations Lab. All filters will be preweighed at the INEL before transport to the cold test pit to establish a baseline weight. The filter will then be placed in a petri-dish and sealed until use at the sampling location. The sampler filter shall be handled using tweezers to minimize contamination of the filter from moisture or natural skin oils from the hand. The filter will be placed on the balance and the initial weight recorded in the project logbook.

Step 2.2 Record the environmental conditions.

Data will be averaged over the time it takes to perform one cut. NOAA will record barometric pressure, wind velocity, humidity, and temperature. NOAA will inform us if the wind speed exceeds $15 \mathrm{mph}$. The wind direction will be assessed by a wind sock $\mathrm{C}$ equivalent at the cold test pit at all times. The wind direction will be recorded every half hour in the logbook. The effects of contamination control methods on the RES will also be recorded in the logbook. 
Step 2.3 Field monitoring and maintenance.

Routine monitoring will be needed during the time that the samplers are operational in the ficld. The RES testing will stop, the vehicle will be turned off, and sampling personnel will conduct a routine safety inspection of the equipment and general area to ensure that no unsafe conditions occur. Then the person will ensure that each sampler is operational and running within operational limits of the flow. Any changes made to the sampler shall be noted in the field logbook.

Step 2.4 Remove overburden using the RES (Step 1) and sample.

A logbook will be kept during setup and conducting of experiments. As a minimum, specific data that shall be included in the logbook for the work performed under this test plan are listed below:

1. The locations of samplers during all tests

2. Flow meter calibration information

3. Computer and setup information

4. Flow rates

5. Computer information including run identifiers, start times, disk file identifiers, and data storage information

6. Filter and smear pre- and postweights

7. Any changes made in experimental or electronic presets

8. Any test abnormalities observed

9. Date and negative numbers of any photographs taken

10. Dates and information on all QA samples (standards, blanks, and duplicates)

11. Any other pertinent information that the experimenter feels is necessary.

12. Total time excavator engine is running and the fuel consumed.

In addition, each page and entry into the logbook shall be dated and initialed by the person making the entry and the INEL Demonstration Manager.

The particulate air samplers will be positioned at several locations at the RWMC. The preweighed particulate filters will be renoved from their petri dish and placed in the filter holder with the retaining ring 
attached. The filter number will be noted in the logbook along with the sampler location. The particulate filter is then ready for sampling.

Sample control will be maintained by placing all filters and smears in a numbered petri-dish after the initial weight is recorded using the system indicated below:

Sample ID $=\mathbf{P} \cdot \mathbf{X}$

where

$$
\begin{aligned}
& P=\text { Particulate air filter } \\
& X=\text { Alpha numeric sample number. }
\end{aligned}
$$

When that sample is used during testing; all pertinent data for that sample will be noted in the logbook as indicated. In addition, plot plans will be used to give a reference to each sample location to note the location and test parameters of each sample taken. These plots will be included as inserts in the logbook. Each insert will be signed and dated.

A chain of custody form will be prepared for each set of samples collected prior to transferring the samples to the analytical laboratory for tracer analysis.

\section{Step 2.4 Procedures for weighing filters after testing}

After sampling, the particulate filters will be dried to remove any excess moisture trapped in the filter during sampling. The samples will then be taken to the weighing area and the filter placed on the balance. The weight will then be recorded in the project logbook. This procedure will be repeated for all filters. After all of the filters have been weighed, the samples will then be transported for tracer analysis.

Step 3. Measure the precision and accuracy of the cut. The survey will consist of the following actions. All readings will be recorded in the field notebook.

\section{Step 3.1 Setup Level}

\section{Step 3.2 Read and Record Rod Level Using control as Backsight}

\section{Step 3.3 Read and Record Foresights}

3.3a Place tape across pit using pipes as a guide

3.3b Place level rod along tape using 2-ft ircrements and/or surface breaks

3.3c Read and record location and rod level.

Step 3.4 Perform Turning Point 
3.4a Read and record rod level using a solid point

3.4b Move and set up level

3.4c Read and record rod level using solid point in step 3.4a

Step 3.5 Read and Record Rod Level Using Control Verify the control elevation

Step 3.6 Calculate foresight elevations in the field notebook after completion of the survey.

Step 4. Use the RCS to perform a characterization survey of the site. At two specific times (2'9" and 4'9" from the surface), the Remote Characterization System will be used to survey the waste area.

Step 4.1 See RCS test plan (EGG-WTD-10704)

Step 5. Go back to step one for another overburden removal cut, if necessary.

Overburden will be removed incrementally at $3^{\prime \prime}, 9^{\prime \prime}, 1^{\prime} 9^{\prime \prime}, 2^{\prime} 9^{\prime \prime}, 3^{\prime} 9^{\prime \prime}, 4^{\prime} 3^{\prime \prime}, 4^{\prime} 6^{\prime \prime}$, and 4'9" from ground level. 


\section{A-3. DATA COMMUNICATION TESTING}

\section{A-3.1 References}

None.

\section{A-3.2 General}

The purpose of this test sequence is to evaluate the data communication system. The RES uses a high speed data wireless local area network for transfer of data and commands.

Performance of the data communications system is primarily affected by operating range, local radio-frequency noise sources, and antenna system performance.

\section{A-3.3 Materlals and Equipment}

This evaluation is to be performed in an open field area. Dimensions should be approximately $2 \times 2 \mathrm{~km}$.

- RES

- Control Station.

\section{A-3.4 Specific Precautions}

None.

\section{A-3.5 Prerequisites}

None.

\section{A-3.6 Procedure}

Step 1 Operating Range. Vehicle operating range shall be determined by observing the communication system error rate at the operations console area. The upper error rate is dependent upon the relative importance of commands versus data and throughput rate. Record the data in the logbook.

Step 2 Antenna System Evaluation. The location of the vehicle and base antennas may impact performance of the communications system. This aspect will be evaluated by driving the vehicle in a circle approximatcly $30 \mathrm{~m}$ diameter at a range of $1 \mathrm{~km}$. Data communications error rates will be monitored as a function of vehicle orientation with respect to the base system. Record the results in the logbook.

Step 3 An additional evaluation of the base system antenna is required. This shall be performed by driving the vehicle around the base system at a constant range of approximately $1 \mathrm{~km}$. Data error rates shall be monitored to detect antenna radiation pattern nulls. Results will be entered into the logbook. 
Step 4 Local interfering sources may be present. Anomalous operating results should indicate the possible existence of such interference. An attempt to locate and identify the noise source will be made. Results will be recorded in the logbook. 


\section{A-4. EXCAVATION TESTS}

\section{A-4.1 References}

None.

\section{A-4.2 General}

The purpose of this test sequence is to test the Remote Excavation System (RES) for retrieving buried wastes. The tests will be performed on the retrieval cells at the cold test pit at the Idaho National Engineering Laboratory. Parameters that will be measured include the time to excavate, dust generated with and without contamination control, and qualitative and quantitative analysis on the remote vs. manual operation of the vehicle. This procedure covers the operations required to take these measurements, as well as recording the time duration of the operation. Contamination control measurements are covered under the Contamination Control Unit Test Plan. The qualitative measurements on remote vs. manual operation are discussed in the human factors analysis test sequence in this test plan.

The step-by-step procedures are given later in this test sequence. Data will be determined valid by the test administrator. If the procedures are deviated from, the test administrator will redline the procedure to reflect those changes.

\section{A-4.3 Materlals and Equlpment}

The following materials and equipment will be required to perform the tests outlined in this test sequence:

- 2 lab notebooks

- 2 pens

- Watch (resolution of one minute)

- Control van and accompanying equipment

- Remote Excavation System

- Tent and associated equipment

- Generator.

\section{A-4.4 Specific Precautions}

1. A snorkel will be attached to the excavator exhaust. Holes will be dug under the wall of the building and the snorkel tube run through the closest hole to the outside of the building. 
2. If required, test operations will cease and a large door in the tent will be opened for approximately 15 minutes to clear the building of exhaust fumes. All personnel in the tent will be equipped with monitors as discussed in the test plan body.

\section{A-4.5 Prerequisites}

1. After the Remote Characterization System survey is complete, approximately 2 days will be required to erect a tent over the area.

2. The Contamination Control Unit (CCU) will be onsite to set up their equipment.

3. Boxes for debris will be placed north of the cells and west of the vehicle.

\section{A-4.6 Procedure}

Following are the step-by-step procedures for testing the Remote Excavation System to retrieve simulated buried waste. Any time that one of the steps refers to recording data, it will be recorded in a logbook. (See Figures 3 and 4.)

Unless otherwise stated, the RES will be operated remotely and waste retrieval operations will be done with the backhoe.

As necessary, retrieval operations will cease while full boxes are removed from the building and replaced with empty boxes.

The starting time and completion time of each step and substep shall be recorded in the logbook (to the nearest minute). In addition, the total amount of fuel consumed over the retrieval operations shall be recorded.

Step 1 Perform excavation of retrieval cell 1 using the following procedure.

Step 1.1 The excavator will be manually driven into the tent and parked north of retrieval cell 1 and the snorkel attached to the exhaust.

Step 1.2 Remove remaining overburden from the retrieval cell 1 and place in boxes.

Step 1.3 Remove 13 drums from retrieval cell 1 and put into boxes.

Step 1.4 Position the RES south of retrieval cell 1.

Step 1.5 Remove remaining overburden from retrieval cell 1 and place in boxes.

Step 1.6 The Contamination Control Unit (CCU) will now begin operations and spay foam and mist as required to provide contamination control. This activity is covered and explained in the CCU Test Plan.

Step 1.7 Remove 13 more drums from retrieval cell 1 and places in boxes.

Step 1.8 CCU will cease operations. 
Step 2 Perform excavation of retrieval cell 2 using the following procedure.

Step 2.1 Position the excavation south of retrieval cell 2.

Step 2.2 Remove remaining overburden from retrieval cell 2 and place in boxes.

Step 2.3 Excavate soil from around the desks buried in retrieval cell 2 and place in boxes.

Step 2.4 Commence retrieval operations to remove desks and place in boxes.

Step 2.5 Abandon desk retrieval operations if unsuccessful.

Step 3 Perform excavation of retrieval cell 3 using the following procedure.

Step 3.1 Position the excavator north of retrieval cell 3.

Step 3.2 Remove the remaining overburc in from retrieval cell 3 and place in boxes.

Step 3.3 Remove 12 drums from retrieval cell 3 and place in boxes.

Step 3.4 With the excavator being operated manually by an operator wearing a bubblesuit, remove 12 drums from retrieval cell 3 and place in boxes.

Step 3.5 Position the excavator south of retrieval cell 3.

Step 3.6 Remove remaining overburden from retrieval cell 3 from this position and place in boxes.

Step 3.7 CCU will now begin operations and spray foam and mist as required to provide contamination control.

Step 3.8 Remove 12 drums from retrieval cell 3 and place in boxes.

Step 3.9 With the excavator being operated manually by an operator wearing a bubblesuit, remove 11 drums from retrieval cell 3 and place in boxes.

Step 3.10 CCU will cease operations.

Step 4 Perform excavation of retrieval cell 4 using the following procedure.

Step 4.1 Position the excavator north of retrieval cell 4.

Step 4.2 Remove the remaining overburden from retrieval cell 4 and place in boxes.

Step 4.3 Remove 10 drums from retrieval cell 4 and place in boxes. 
Step 4.4 With the excavator being operated manually by an operator wearing a bubblesuit, remove 10 drums from retrieval cell 4 and place in boxes.

Step 4.5 CCU will now begin operations and spray foam and mist as required to provide contamination control.

Step 4.6 Position the RES south of retrieval cell 4.

Step 4.7 Remove the remaining overburden from retrieval cell 4 from this position and place in boxes.

Step 4.8 Remove 9 drums from retrieval cell 4 and place in boxes.

Step 4.9 With the excavator being operated manually by an operator wearing a bubblesuit, remove 9 drums from retrieval cell 4 and place in boxes.

Step 4.10 CCU will cease operations. 


\section{A-5. EVALUATION OF THE CAMERA SYSTEM}

\section{A-5.1 References}

None.

\section{A-5.2 General}

The purpose of this test sequence is to evaluate the video telemetry system. The purpose of the video telemetry systems test is to evaluate the performance of the video telemetry system mounted on the RES. Aspects to be examined include:

1. Adequacy of the video image

2. Adequacy of the pan and tilt control

3. Adequacy of the radio-frequency telemetry link.

\section{A-5.3 Materials and Equipment}

This evaluation is to be performed in an open field area. Dimensions should be approximately $2 \times 2 \mathrm{~km}$.

- $\quad$ RES

- Control Station.

\section{A-5.4 Specific Precautions}

The evaluation of this system is based primarily on subjective measures.

\section{A-5.5 Prerequisites}

None.

\section{A-5.6 Procedure}

Step 1 Image Quality. This entails evaluating the resolution of the image both for objects close-in and distant. Record the qualitative operator thoughts on the image quality in the logbook. In addition, note in the logbook if objects could be sufficiently recognized so that the objects could be avoided.

Step 2 Range of Motion. The pan and tilt position range and camera view based on location on the RES should be noted in the logbook. The location should minimize the blind spots and maximize the necessary field of view for operations.

Step 3 Image Stability. This entails recording the image stability while the vehicle is in motion. If vehicle vibrations are significant, operator fatigue will occur more rapidly. 
Step 4 Multiplexer Operation. Test multiplexer operation by interchanging camera signals between the transmitters. Record the data in the logbook.

Step 5 Range Limitations. Determine the maximum range of operation based on image quality. An image suitable for safe operation is required. This value will be recorded in the logbook and a safety factor applied.

Step 6 Identify parameters that may affect operation of the vehicle not specifically identified above. 


\section{A-6. YIELD MEASUREMENTS FOR OVERBURDEN REMOVALS AND EXCAVATION}

1. Purpose-This procedure defines the process of measuring yields generated in RES demonstration operations using the front end loader or backhoe. The EG\&G Idaho BWRP principal investigator is responsible for these determinations.

2. INEL RWMC Waste Storage Box-This plywood box, pallet mounted, with typical outer dimensions of $4 \times 8 \times 4 \mathrm{ft}$ will be used to contain cold test soil material retrieved during overburden and excavation of waste form operations (bubble-suited, remote) using the RES. The waste storage box has inner supports at each end ( $4 \times 4$ in. posts), along the 8 ' sides ( 3 each $2 \times 4$ in. posts at roughly $2 \mathrm{ft}$ spacing) and along the $4 \mathrm{ft}$ ends ( 1 each $2 \times 4$ in. at center). The inside dimensions of the box are:

- Length: $94.5 \pm 0.25$ in.

- Width: $\$ 6.5 \pm 0.25$ in.

- Height: $46.25 \pm 0.43$ in.

The volume of the container filled to the top is $117.6 \mathrm{ft}^{3}$. During retrieval operations the containers are not to be overfilled.

3. Effector Capacities

Front End Loader-20.2 $\mathrm{ft}^{3}$

- $\quad$ Backhoe-7 $\mathrm{ft}^{3}$.

Assuming that each load will be within -50 to $+20 \%$ of capacity, the number of loads to fill a waste container will vary between 5 and 11 loads for the front end loader and between 13 and 33 loads for the backhoe. Contents of each waste box will be restricted to a single RES operational mode (bubble-suited or remote).

4. The following data will be acquired and recorded in the logbook:

- The cell being excavated

- The retrieval location (north or south of the pit)

- A count of the individual load cycles to fill a box

- The time to load a particular box

- An estimate of the volume of retrieved waste and percent of void space

- Number of drums per box

- The total number of boxes at that location 
- Initials of individual completing logbook entry

- Box identification number.

5. Volume Measurement-After removal of loaded waste containers from the retrieval cell, determine volumetric yield by one of the following methods:

A. The box contains primarily soil

1. Compact material within box to eliminate voids and level the surface of the soil using hand tools (shovel, rake, board, etc.)

2. Measure the distance from soil level to top of waste container at a minimum of four (4) locations within container at support locations (in inches)

3. Record surface level results in logbook

4. From Figure A-5, record the volume of the soil in the logbook.

B. The box contains primarily odd shaped debris

1. Estimate the volume produced

- By visual observation, estimate the percentage that the box is full and record it in the logbook

- In the logbook provide a brief description of the items in the box (i.e., six 55-gal drums)

- Record the number of boxes filled from each cell.

2. Estimate the volume retrieved

- During retrieval, count the number of drums retrieved and record in logbook how many placed in each box (by box number)

- By visual inspection of the pit, estimate the percentage removed from the pit and record in the logbook

- Record the number of boxes filled from each cell. 


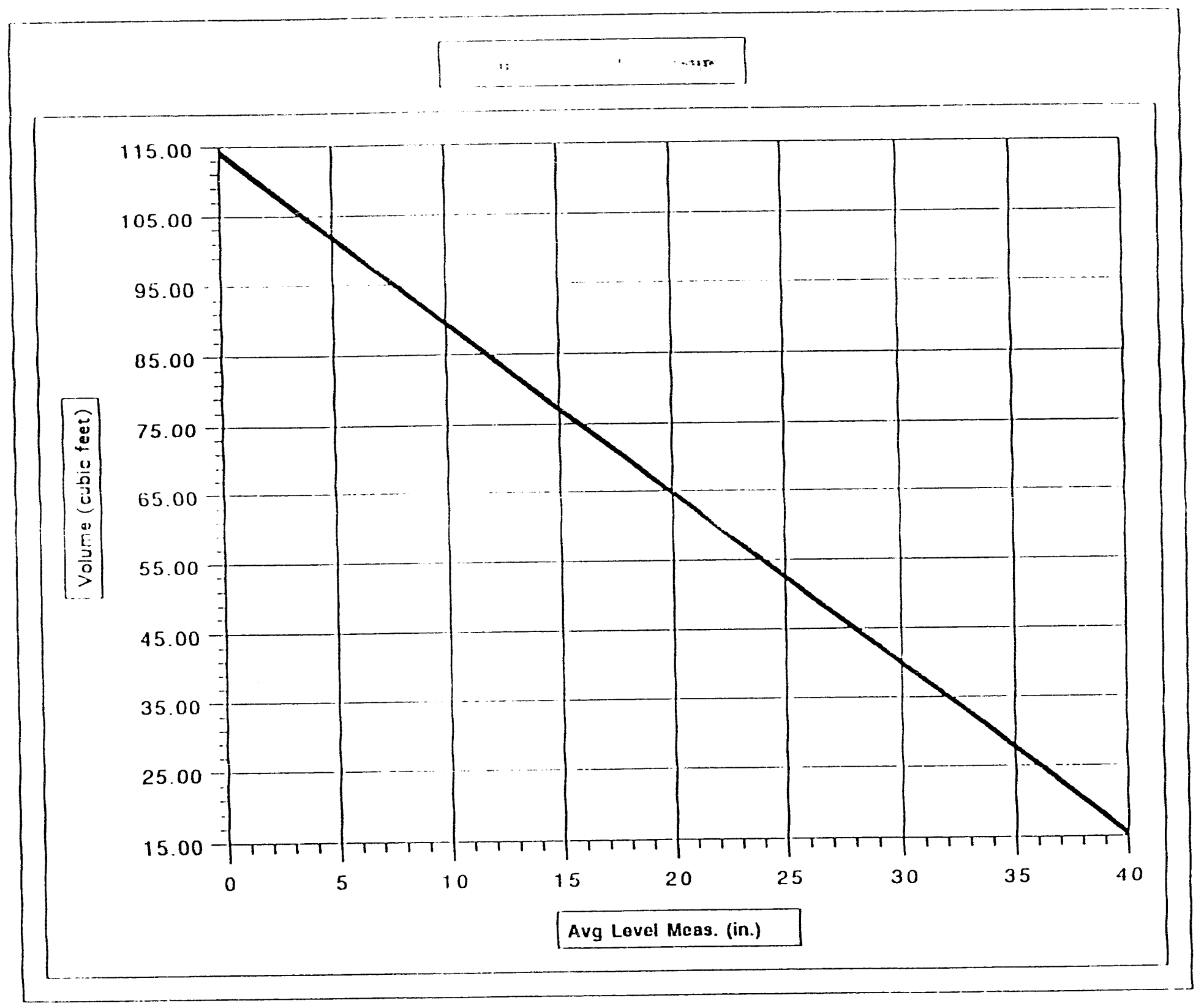

Figure A-5. Yield volume. 
Appendix B

Formulas for DQO Calculations

B-1 
B-2

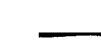

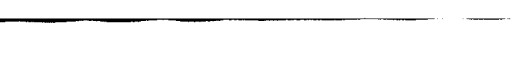

$$
\text { B-2 }
$$




\section{Appendix B}

\section{Formulas for DQO Calculations}

\section{Notation}

For each of the measurement processes under consideration, the proposed tests are to determine properties of the process. More precisely, the variance and bias of the measurement process are to be estimated. The variance and bias correspond to the precision and the accuracy, respectively, of the measurement process. For definitions of mean, variance, and bias, see any statistics text.

Let $M$ denote a measurement, and let $\sigma_{\text {meas }}^{2}$ denote the variance of the measurement process. If $n$ measurements are taken, denote them by $M_{\mathrm{i}}$, and denote their average by $\bar{M}$. Define the sample variance

$s_{\text {meas }}^{2}=[1 /(n-1)] \Sigma\left(M_{\mathrm{i}}-\bar{M}\right)^{2}$.

We use $s_{\text {meas }}^{2}$ to estimate $\sigma_{\text {meas }}^{2}$

Suppose also that the measurement process is intended to measure some true value $T$. The bias $\mathrm{B}$ is defined as the difference of the long-term average measurement and the true value. $\bar{M}$ approximates the long-term average measurement, but is not exactly the same because $\bar{M}$ only involves $n$ measurements. The true value is known, approximately, in a test situation. Therefore, the bias $B$ can be estimated in a test situation by

$\hat{B}=\bar{M}-$ (approximation of true value).

\section{Estimation of $\sigma^{2}$ meas}

It is shown in upper division statistics texts such as Mood, Graybill, and Boes (1974) that $s_{\text {meas }}^{2}$ is an unbiased estimator of $\sigma_{\text {meas }}^{2}$, that is, $s^{2}$ estimates $\sigma^{2}$ with perfect accuracy. Consider now the precision of $s^{2}$. Assuming that the measurements are independent and normally distributed, a $95 \%$ confidence interval for $\sigma^{2}$ is

$(n-1) s^{2} / \chi_{0.975}^{2} \leq \sigma^{2} \leq(n-1) s^{2} / \chi^{2} 0.025$

where $\chi_{0.975}^{2}$ is the 97.5th percentile of a $\chi^{2}$ distribution with $n-1$ degrees of freedom, and $\chi_{0.025}^{2}$ is the 2.5 th percentile. If $n=5$, this interval becomes

$4 s^{2} / 11.1 \leq \sigma^{2} \leq 4 s / 0.484$

$0.36 s^{2} \leq \sigma^{2} \leq 8.26 s^{2}$

so that $\sigma^{2}$ is within a factor of 10 of $s^{2}$, as required by the DQO. We remark that it follows therefore that $\sigma$ is within a factor of 3 of $s$. 


\section{Estimation of B}

We assume that the test was set up so that the approximation of the true value is an unbiased estimate of the true value. That is, any one approximation may be too high or too low, but the average over many possible setups is the true value. For example, if subsidence is a contributor to the uncertainty in the location of a buried object, the approximate location used in the calculations includes an estimate of the subsidence, which may be too high or too low. The variance of the approximation to the true value is denoted $\sigma_{\text {true }}^{2}$ and must be estimated by knowledge of the test setup. For example, if the true value is the location of a buried metal object, contributors to $\sigma_{\text {true }}^{2}$ would include measurement error in recording the location (possibly negligible), shifting of the object when dirt was pushed around it and over it, and later subsidence. The magnitude of the error must be estimated by considering the nature of these contributors.

Use $\hat{B}$, defined above, to estimate the bias $B$. Because $\bar{M}$ is an unbiased estimator of the long-term average measurement, and the approximation of the true value is assumed to be an unbiased estimator of the true value, it follows that $B$ is an unbiased estimator of $B$, that is, $B$ has perfect accuracy. Now consider the precision. The variance of $\hat{B}$ is

$$
\begin{aligned}
\operatorname{var}(\hat{B}) & =\operatorname{var}(\bar{M})+\operatorname{var} \text { (approximation of the true value) } \\
& =\sigma_{\text {mess }}^{2} / n+\sigma_{\text {true }}^{2}
\end{aligned}
$$

and the standard deviation is the square root of $\operatorname{var}(\hat{B})$. A guess for this value, before any measurements have been taken, is based on expert guesses of the values of the two $\sigma$ 's. If desired, conservative guesses can be used.

For use with the DQOs, we use these (possibly conservative) guesses and then sax that with $95 \%$ probability the difference $B-B$ will be in the range $\pm 2 \times$ (estimated st. dev. of $B$ )

\section{Reference}

Mood, A. M., F. A. Graybill, and D. C. Boes, 1974, Introduction to the Theory of Statistics, Third Edition, New York: McGraw-Hill. 

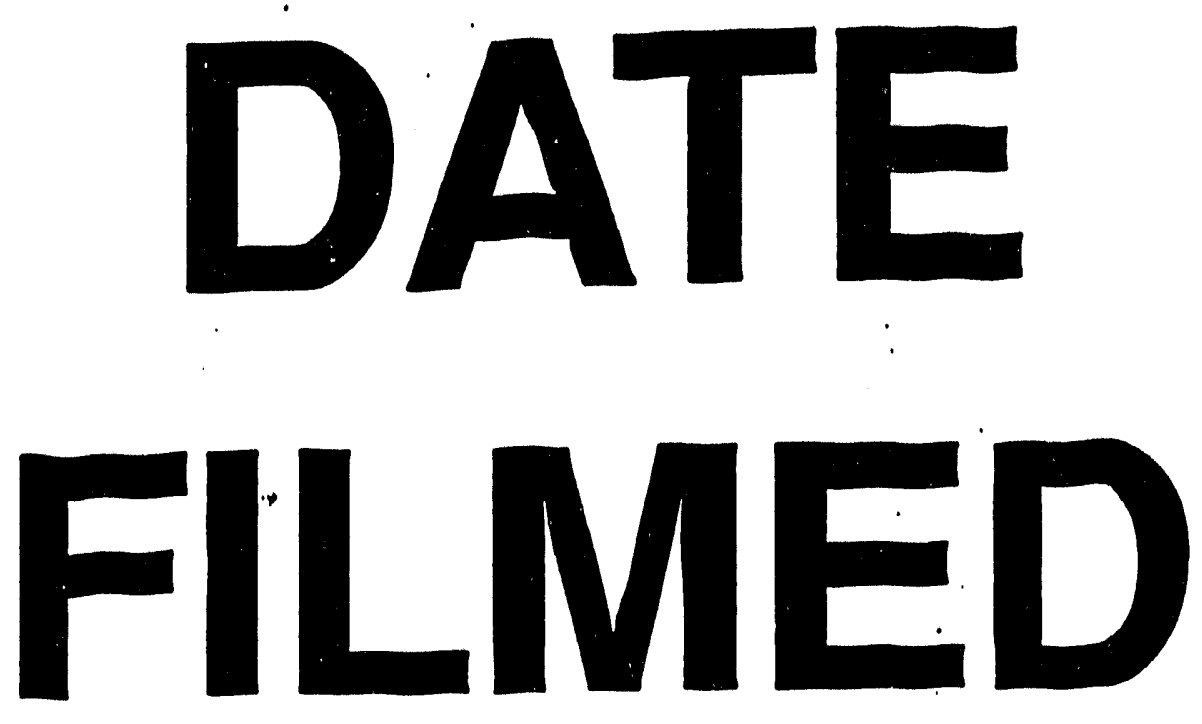

$1 / 10 / 94$
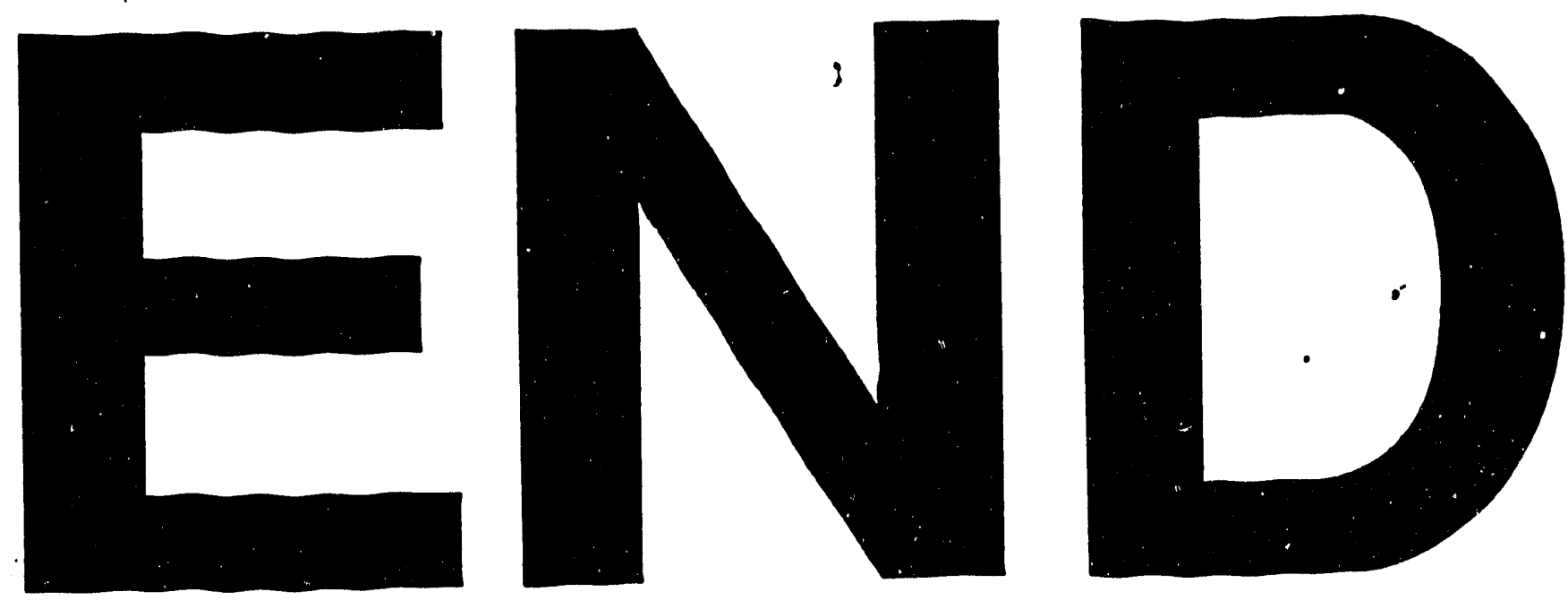
